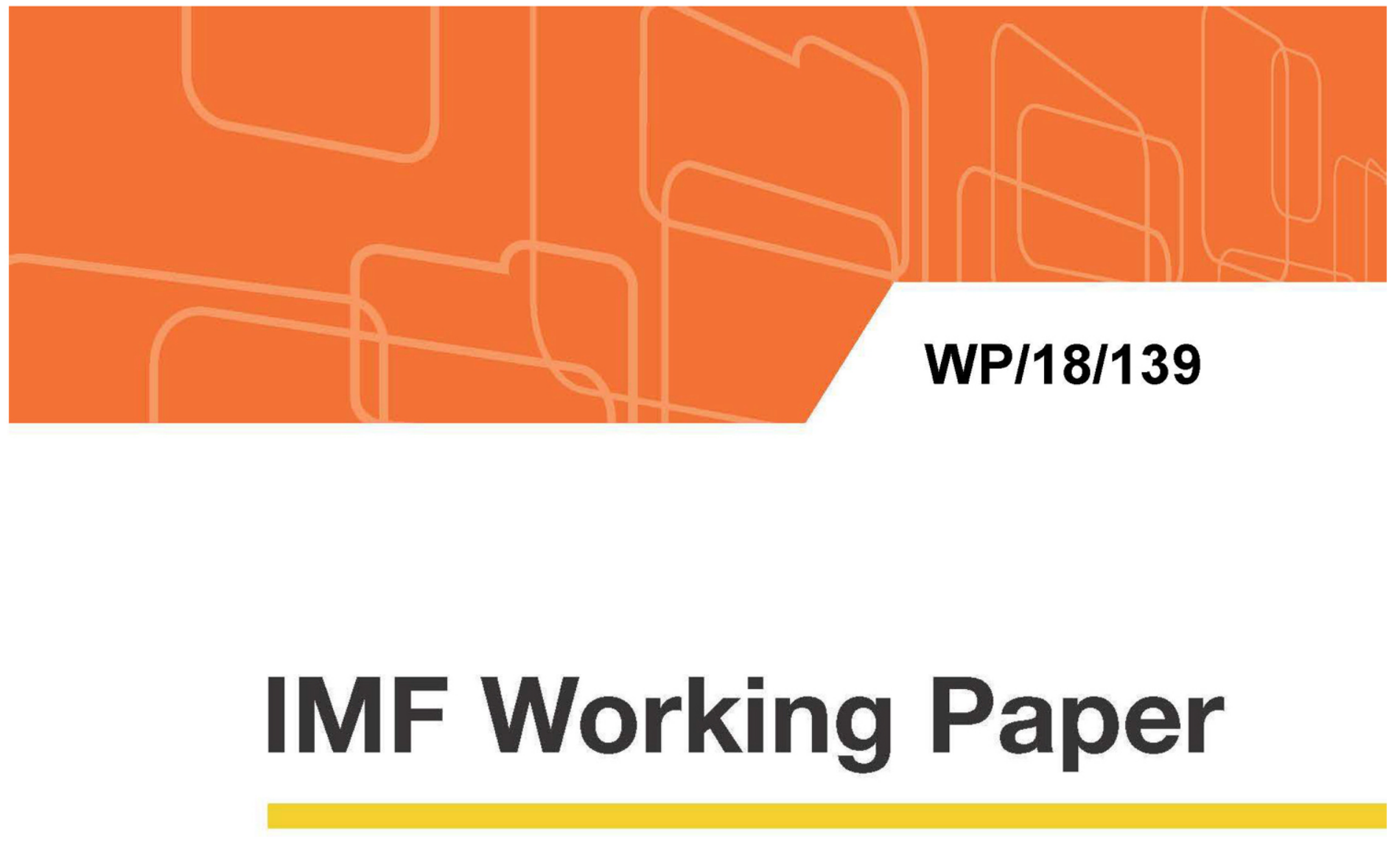

\title{
Determinants of U.S. Business Investment
}

\author{
by Emanuel Kopp
}

IMF Working Papers describe research in progress by the author(s) and are published to elicit comments and to encourage debate. The views expressed in IMF Working Papers are those of the author(s) and do not necessarily represent the views of the IMF, its Executive Board, or IMF management. 


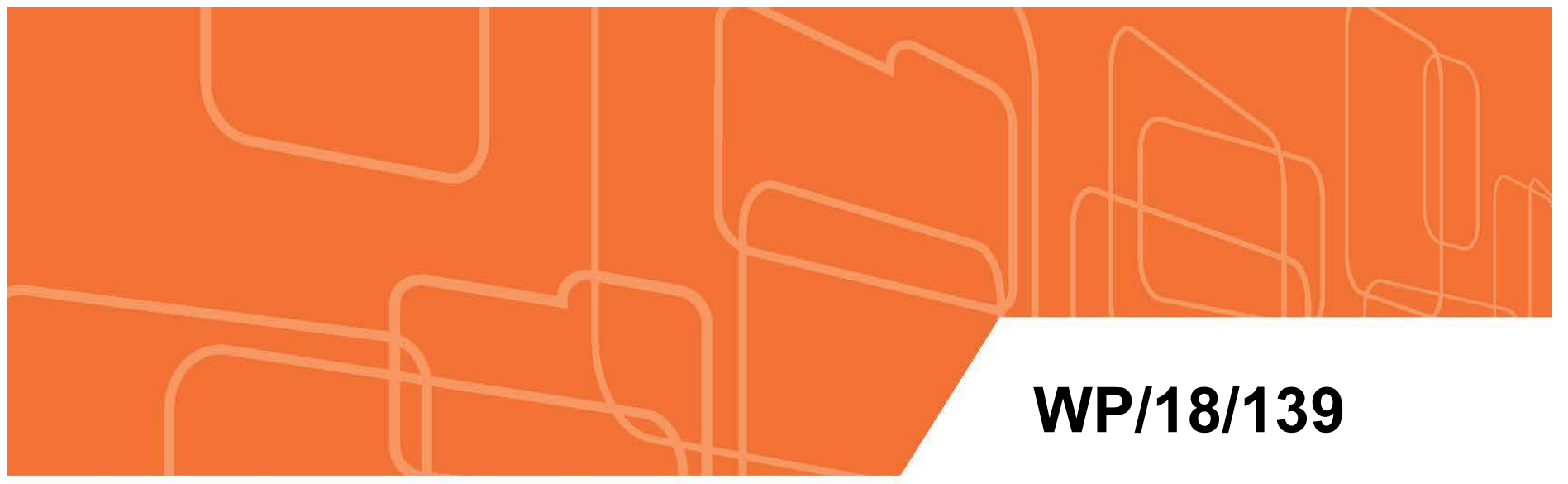

\section{IMF Working Paper}

\section{Determinants of U.S. Business Investment}

by Emanuel Kopp

IMF Working Papers describe research in progress by the author(s) and are published to elicit comments and to encourage debate. The views expressed in IMF Working Papers are those of the author(s) and do not necessarily represent the views of the IMF, its Executive Board, or IMF management.

$$
\text { I N T ER N A T I O N A L M O N E T A R Y F U N D }
$$




\title{
IMF Working Paper
}

Western Hemisphere Department

\section{Determinants of U.S. Business Investment}

Prepared by Emanuel Kopp

Authorized for distribution by Nigel Chalk

June 2018

\section{IMF Working Papers describe research in progress by the author(s) and are published to elicit comments and to encourage debate. The views expressed in IMF Working Papers are those of the author(s) and do not necessarily represent the views of the IMF, its Executive Board, or IMF management.}

\begin{abstract}
U.S. business investment has taken a serious toll during the global financial crisis and also in the recovery phase investment did not pick up as expected. What is surprising is that the alleged investment slowdown happened at a time of record corporate profits and retained earnings, highly supportive financial conditions, improved sentiment, rising equity valuations, and strong labor markets - factors established in supporting business investment. Applying accelerator models and Bayesian Model Averaging, this paper discusses the extent to which U.S. business investment has been unusual. Results suggest that cautious expectations of future aggregate demand growth explain most of the weakness in investment, and that the oil and gas sector accounts for a considerable portion of the investment slump. Consequently, the behavior of U.S. business investment in recent years has not been unusual once these factors are taken into account. Also, there is little evidence for uncertainty holding back investment, or firms' financial measures "crowding out" capital expenditure.

JEL Classification Numbers: D5, D62, D82, G2, H41.

Keywords: private fixed investment, accelerator models, Bayesian Model Averaging.

Author's E-Mail Address: ekopp@,imf.org.
\end{abstract}


ABSTRACT _______ $\underline{\mathbf{2}}$

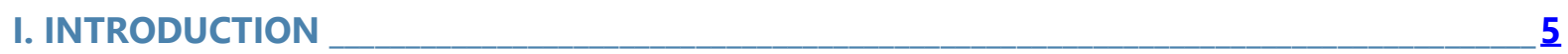

II. STYLIZED FACTS ABOUT U.S. BUSINESS INVESTMENT _____ $\underline{\mathbf{8}}$

III. MACROECONOMIC FACTORS _____ 11

A. Investment and Aggregate Demand Growth ________ 11

B. Forward-looking Accelerator Model________ 13

C. Accelerator Models Augmented with Macroeconomic Variables_______ 15

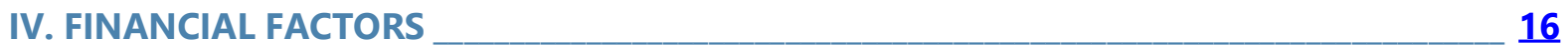

A. Strategic Decision Making by Firm Executives______ 16

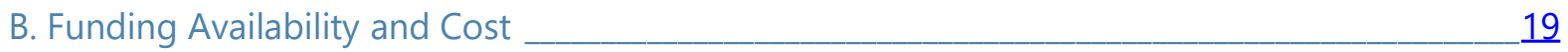

C. Accelerator Models Augmented with Financial Variables________ 19

V. POLITICAL ECONOMY FACTORS ___

VI. BAYESIAN MODEL AVERAGING_______ $\underline{\mathbf{2 2}}$

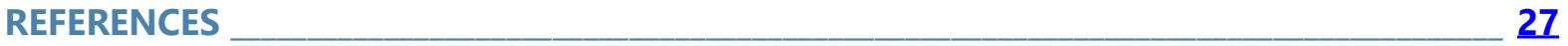

ANNEX TABLE $1 \ldots$

ANNEX TABLE 2_______ 31

FIGURES

1: Conditions for Investment (1994-2017)_______ $\underline{5}$

2: Investment and Aggregate Demand (1997-2017) ____ _ 6

3: Long-term Trends in Investment (1983-2017)_______ 7

4: Residential and Nonresidential Investment since the Crisis (2005-2017)_________

5: Employment and Investment over the Last Business Cycles (1997-2017)______

6: Contribution to Growth (1980-2017) _____ 10

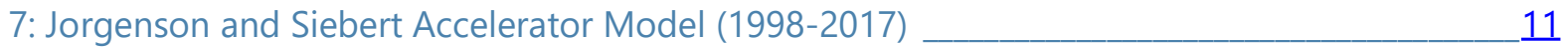

8: Equipment, Structures, and IP (2015-2017), log index______ 12

9: Relative Price of Investment, and Depreciation of Capital Stock, percent_______ 13

10: U.S. Energy Sector: Market Leverage, ETF Volatility, and Investment ________ 14

11: Forward-looking Accelerator for Equipment (1908-2017) ________ 14

12: U.S. Energy Sector: Market Leverage, ETF Volatility, and Investment _______ 15

13: Real Investment vs. Financial Measures (1981-2016) _____ 17

14: International Perspective______ 18

15: Demand for Credit, Lending Standards, and Corporate Funding Costs______ 18

(CInternational Monetary Fund. Not for Redistribution 
16: Accelerator Models with Financial Factors

17: Accelerator Models with Political Economy Factors

18: Bayesian Model Average, Non-oil: Predictors

19: Bayesian Model Average: Predictors

$\underline{25}$

\section{TABLES}

1: Bayesian Model Averaging, Non-oil: Prosterior Probabilities and Means 


\section{INTRODUCTION}

There has been an intense debate about the slowdown of U.S. business investment. For much of the current recovery, investment growth has been lackluster despite record corporate profits, highly supportive financial conditions, robust business and consumer sentiment, rising equity valuations, and improving labor markets (Figure 1). There is no agreement on how U.S. business investment has been performing after the global financial crisis. Some suggest that investment growth since the crisis has been consistent with the general weakness in activity. ${ }^{1}$ Others find that special factors and conditions have held back the recovery in investment. For instance, Baker and Bloom (2013) and Gilchrist et al (2014) argue that uncertainty has held back investment. Campello et al (2010) blame financial frictions and weakness in the banking sector. Arif and Lee (2014) argue that low investor sentiment can depress investment growth.

\section{Figure 1: Conditions for Investment (1994-2017)}
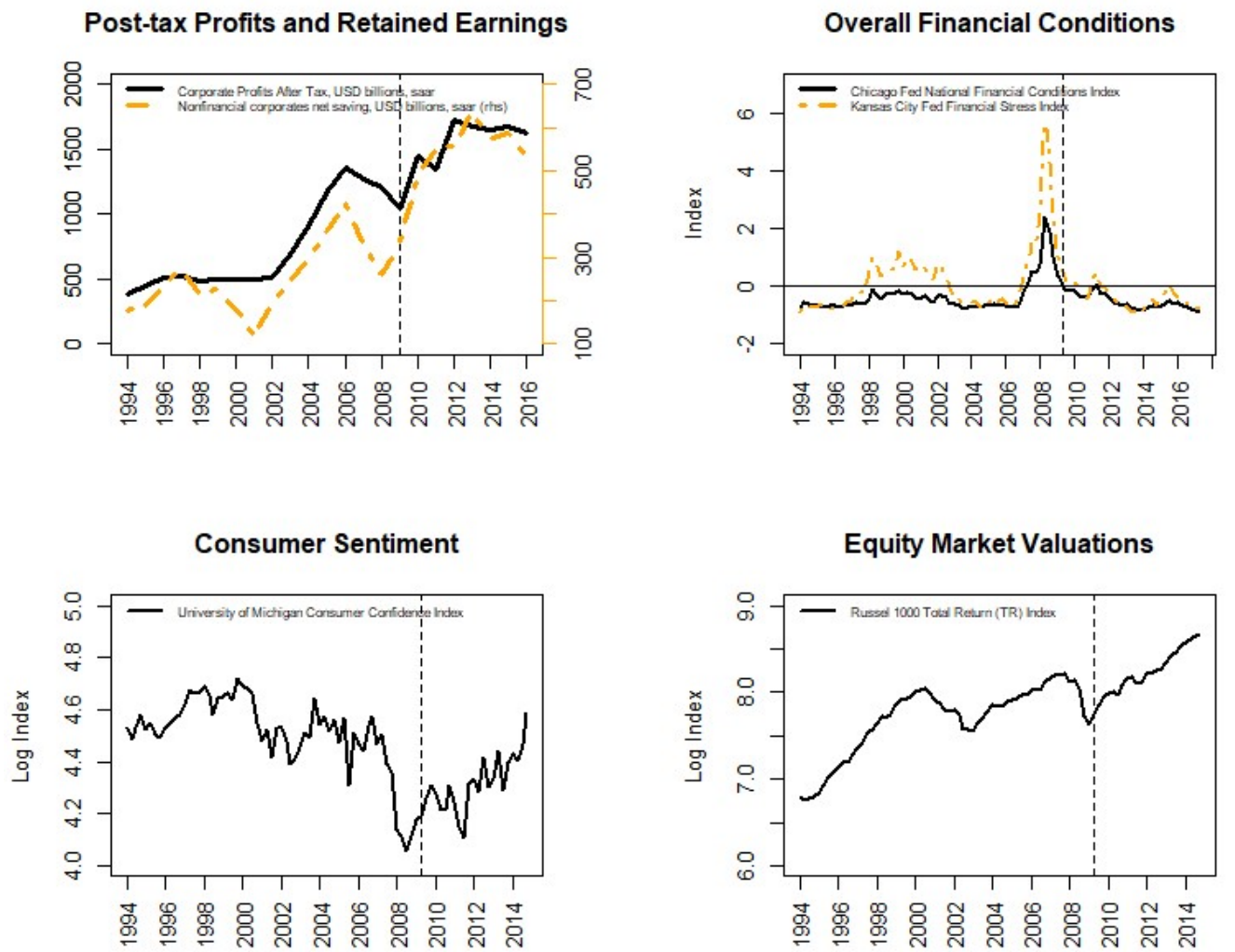

Source: BEA, Federal Reserve, Haver, NBER. Author's illustration.

I am grateful to Nigel Chalk, Federico J. Diez, Zsoka Koczan, Daniel Leigh, and Andrea Pescatori for helpful comments and suggestions. All remaining errors and omission are mine.

${ }^{1}$ Banerjee et al (2015) and Kothari et al (2017), among others. The IMF's April 2015 World Economic Outlook (WEO) found that the contraction in private investment during and after the global financial crisis has affected all advanced economies, albeit to different extent; was broad-based; and mainly due to weak aggregate demand. 
While investment theories are well established theoretically, empirical studies have not reached consensus on which factors systematically drive private investment. The relationship between investment and growth has been studied for more than a century. Early studies by Mises, Hayek, and Schumpeter focused on over- and underinvestment and suggested that booms, characterized by high growth expectations and easy financing conditions, are likely to be associated with overinvestment, and vice versa - cyclical properties that still hold today. Firms invest too long into expansions, and hesitate to invest after small as well as large demand shocks (Figure 2). Most of the early empirical studies also concluded that rich equity valuations coincide with strong business investment, irrespective of actual returns on investment.

Figure 2: Investment and Aggregate Demand (1997-2017)

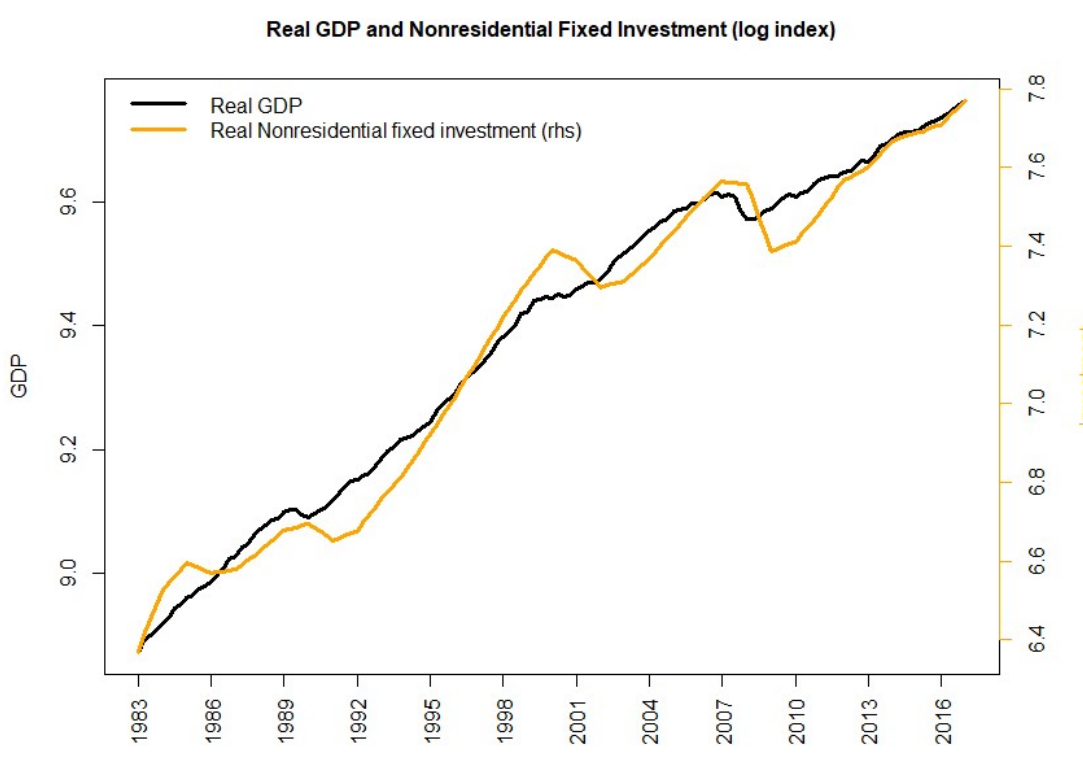

Source: BEA. Author's illustration.

Numerous reasons have been alleged of pulling down investment. Macroeconomic factors include weak aggregate demand but also technological progress and its impact on capital expenditure; a strong dollar depressing export growth; and crisis in specific sectors of the economy. Separately, financial factors and financial frictions, like limited or only costly access to funding, restrictive lending policies, or misaligned executive compensation incentives linked to stock options have been blamed for the weak recovery in private investment. Also, a number of political economy factors have likely been associated with the post-crisis investment puzzle. Uncertainty about economic policies, political conflict and Congressional gridlock, depressed producer or consumer sentiment, or a tax system that arguably disincentives fixed investment could have been driving forces. Ultimately, it is unlikely that a single cause or 
factor has been responsible for actual investment growth outcomes. Rather, it is a combination of different, potentially related factors. ${ }^{2}$

The main finding of this paper is that post-crisis U.S. business investment has not behaved unusually but been in line with what weak expected demand growth suggested, which explains most of the sluggish capital formation since the financial crisis. The marked decline in global oil prices has further weighed on oil and gas investment between 2014 and end-2016. This would suggest that, with expectations of future demand growth generally trending upwards, and with oil and gas activity starting to recover, business investment should strengthen over the near-term.

The remainder of this paper is as follows: Section II presents stylized facts about investment in the U.S. economy. Sections III, IV, and V delve into the relationship between investment and macroeconomic, financial, and political factors, respectively. Section VI applies Bayesian model averaging to identify which factors matter most, and assesses the joint predictive power of suspected investment drivers. The Annex contains a description of the variables applied.

Figure 3: Long-term Trends in Investment (1983-2017)

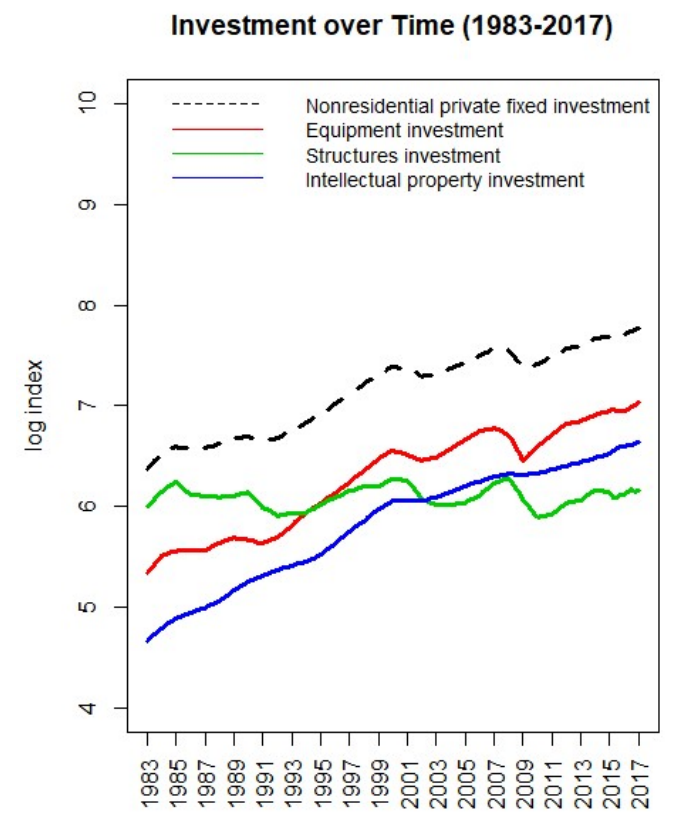

Decomposition of Investment (1983-2016)

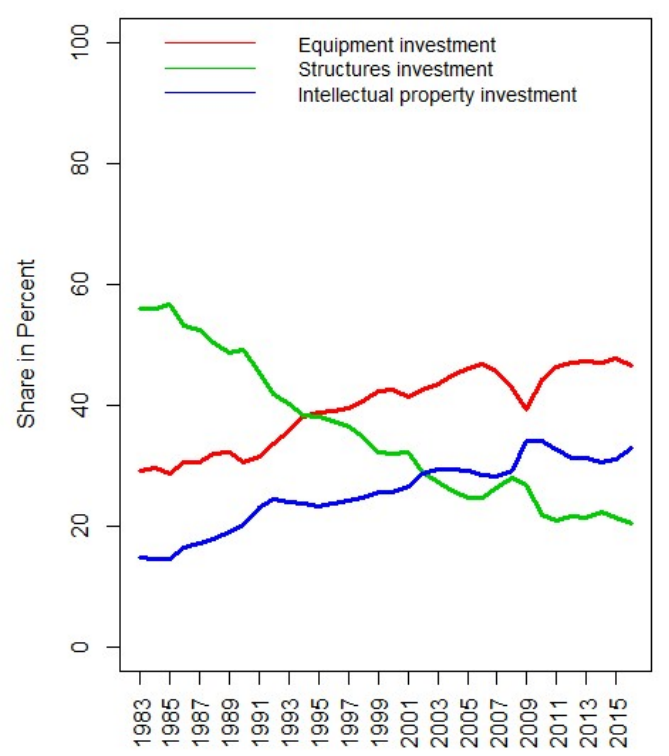

Source: BEA, Haver. Author's illustration.

\footnotetext{
${ }^{2}$ Factors that are not discussed in this paper but may help explain the behavior of business investment include specifically: rising corporate market power; shifting demographics; and the role of unconventional monetary policy. These factors may be subject to future research.
} 


\section{STYLIZED FACTS ABOUT U.S. BUSINESS INVESTMENT}

Private fixed investment (PFI) is a measure of additions to and replacements of the U.S. capital stock of private fixed assets (BEA, 2017). Specifically, PFI includes the creation of new productive assets, the improvement of existing assets, as well as the replacement of depreciated or no longer needed assets. PFI measures spending by the private sector on fixed assets in the U.S. economy, and is a decent indicator of the willingness to expand production capacity or demand for housing. As PFI is the largest category of investment, and its behavior is a key input into macroeconomic forecasts.

PFI can be broken down to PFI into (i) equipment, (ii) structures, and (iii) intellectual property (IP). Fixed investment in equipment and structures are highly cyclical components of GDP, whereas investment in IP is relatively immune to cyclical swings (Figure 3, left chart). Total nonresidential private fixed investment (NPFI) now constitutes 13 percent of GDP. Investment in structures saw its share drop from 65 percent of NPFI in the late 1960s to only 21 percent by end 2016, while IP and equipment investment subsequently took larger shares (right chart). Since the 1980s, investment in structures has lost importance compared to other categories (right chart), and by the mid-1990s, equipment investment became the largest component of NPFI. IP investment did not experience the slump seen in equipment and structures investment and, hence, was the bright spot in the recovery phase.

\section{Figure 4: Residential and Nonresidential Investment since the Crisis (2005-2017)}
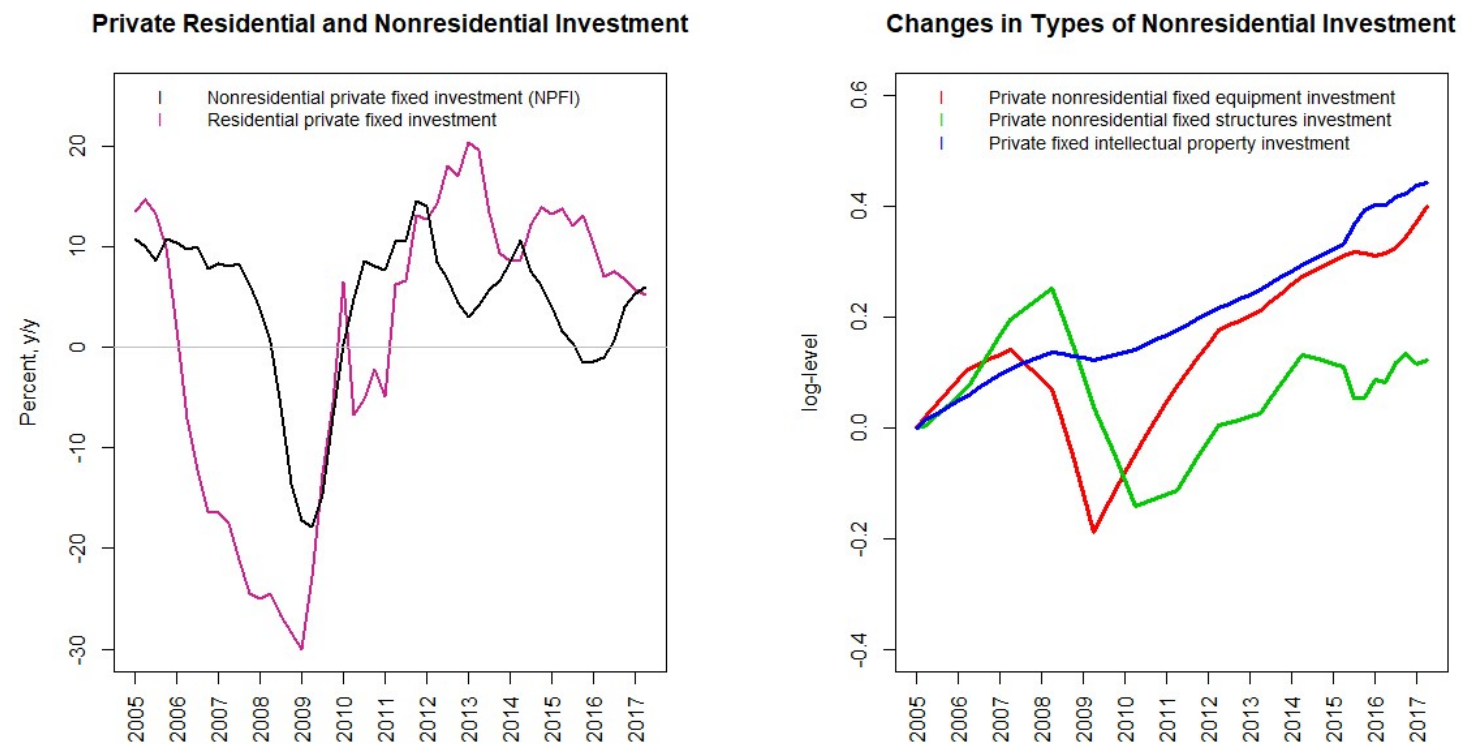

Source: BEA, Haver. Author's illustration.

Business investment has taken a serious toll during the global financial crisis (GFC), and also during the recovery phase investment did not pick up as expected. Residential investment played a key role in the housing bubble that lead to the GFC, but the weakness in investment 
has been much broader, affecting nonresidential private fixed investment (NPFI) as well. Between end-2007 and mid-2009, equipment investment dropped by 30 percent, before rebounding by more than 40 percent until end-2015 (Fig. 4, right chart). In 2016, however, investment growth was at, derailing the post-GFC investment recovery. Structures investment appears to have taken a permanent hit, from which it never fully recovered. IP has been more or less immune to the drop in aggregate demand, and continued to grow in line with its pre-crisis trajectory. Since fall 2010, the labor market has been experiencing the longest consecutive creation of jobs on record, but the growth in business investment has become considerably more volatile with respect to employment growth (Figure 5).

Figure 5: Employment and Investment over the Last Business Cycles (1997-2017)

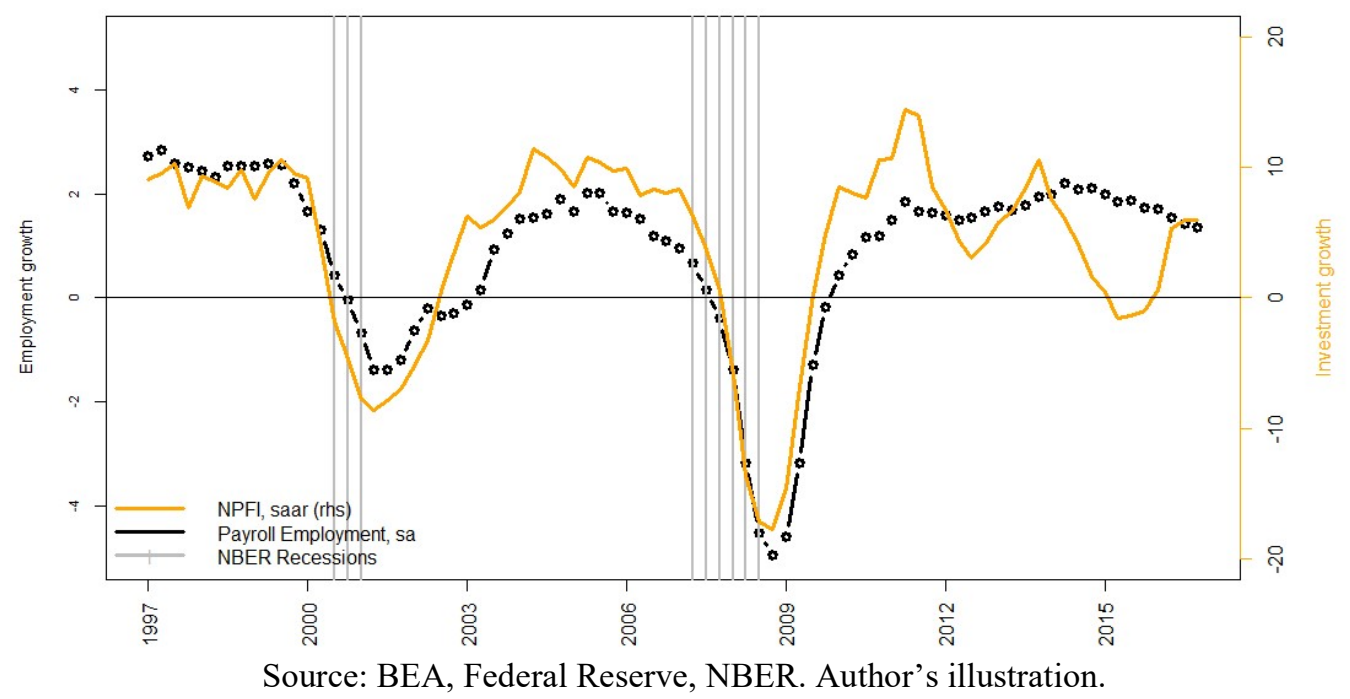

While consumption has been the engine of growth in the U.S., investment has been rather choppy. Figure 6 shows the growth contribution of personal consumption, NPFI ("business investment") and its components, and RPFI. Private consumption has recovered quickly after the 2008 shock. While muted initially (adding around one percent a year to growth), strong consumption growth later boosted output by around 1.5 percent a year. Business investment, on the other hand, saw the opposite pattern (especially equipment investment). In 2016, weak business investment contributed negatively to GDP, which is rare outside recessions. RPFI, however, recovered steadily and eventually returned to its typically contribution to growth.

The weakness in business investment was not limited to the U.S. economy but impacted all advanced countries, with nonresidential investment dropping 10-25 percent during the global financial crisis (GFC). ${ }^{3}$ This commonality suggests that factors that tend to be overwhelmingly idiosyncratic - like regulations, tax law, and to some extent demographic trends - are unlikely to systematically depress investment growth.

\footnotetext{
${ }^{3}$ See Banerjee et al, 2015, and IMF, 2015.
} 
Figure 6: Contribution to Growth (1980-2017)
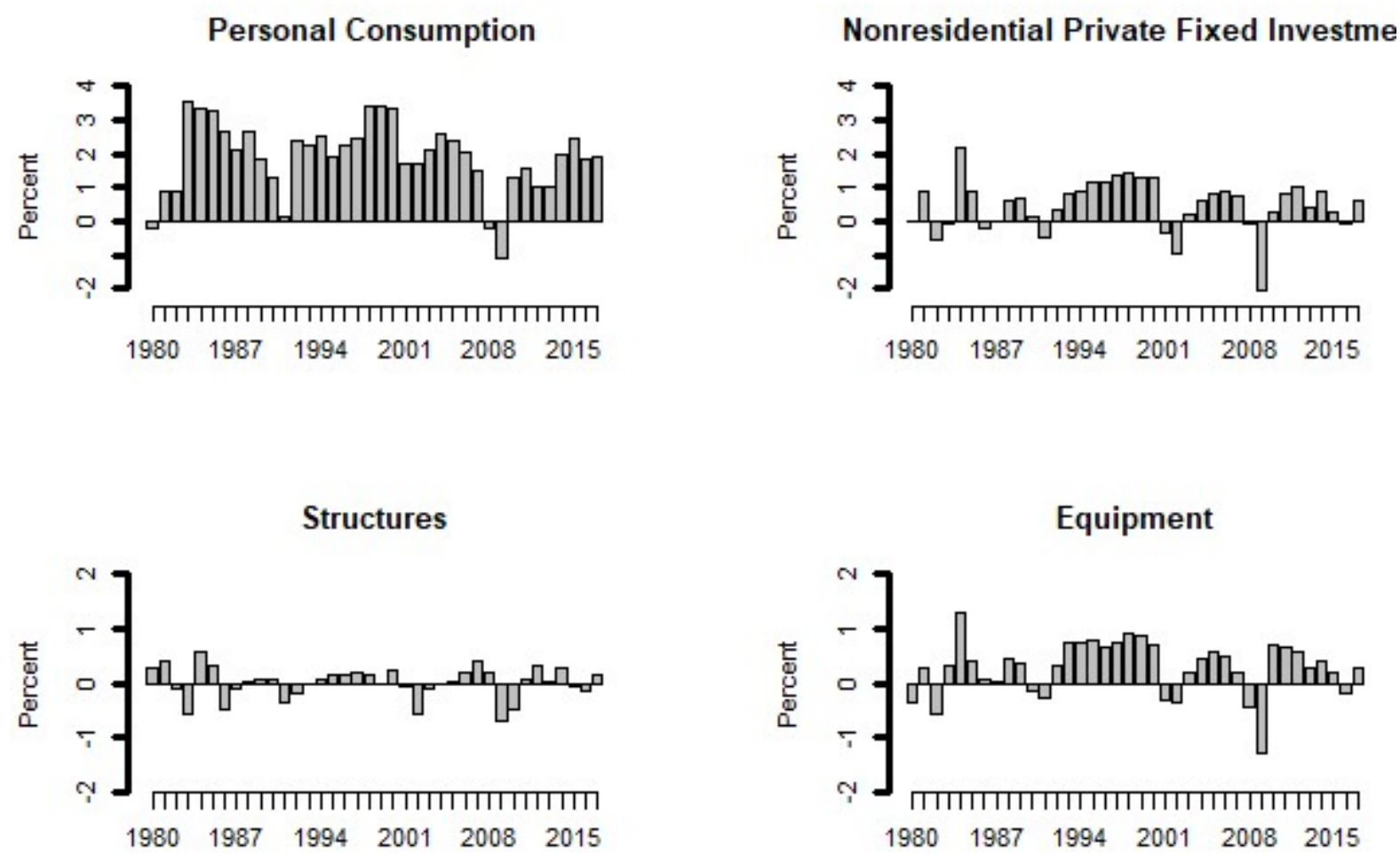

Intellectual Property Products

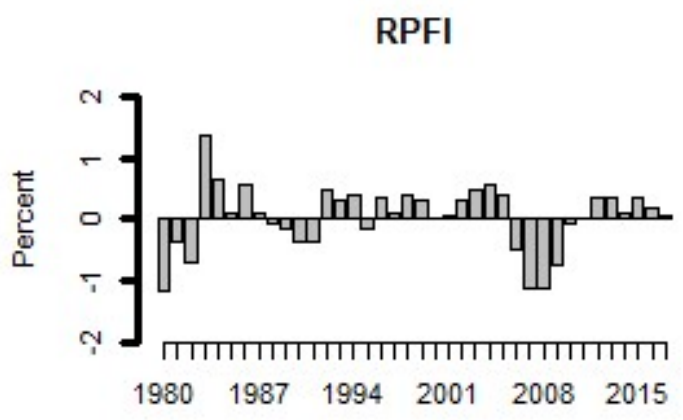

Source: BEA, Haver. Author's illustration. 


\section{MACROECONOMIC FACTORS}

Among macroeconomic factors, weak aggregate demand has typically been found to be the proximate cause of low investment. In Samuelson's (1939) neoclassical accelerator model, a representative firm with constant returns to scale selects the level of capital that maximizes the expected value of future profits. According to the theory, it is not high profits or earnings that make a firm invest but rather the firm's expectation of future demand. Investment increases (decreases) when the growth in aggregate demand is expected to accelerate (decelerate), i.e., investment growth is driven by the acceleration in output. More modern variants of the accelerator model, like in Pinto and Tevlin (2014), IMF (2015), and Banerjee et al (2015), are based on the same properties but more generalized and allow for additional explanatory factors. However, there is less agreement on which other macroeconomic factors besides aggregate demand growth help explain business investment. For instance, the level of interest rates does not appear to be predictive of investment growth, and coefficients often do not even show the expected sign (Kothari and others, 2017). There is more agreement on the role played by changes in the relative price of investment. Physical investment has become relatively cheaper and, hence, investment requires increasingly less funds.

Figure 7: Jorgenson and Siebert Accelerator Model (1998-2017)
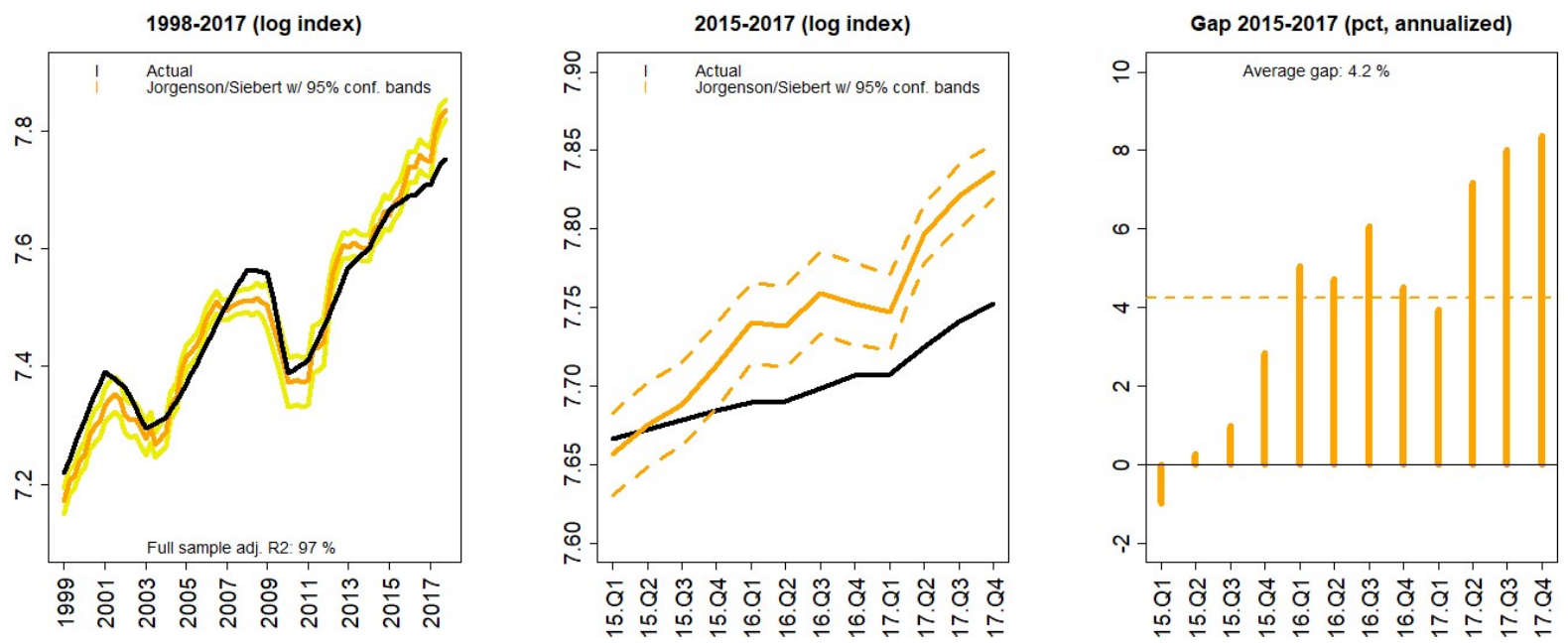

Source: BEA. Author's estimations.

\section{A. Investment and Aggregate Demand Growth}

Accelerator models aim to explain the extent to which investment activity is driven by aggregate demand growth. The Jorgenson and Siebert (1968) derivation of the accelerator model is empirically estimated using the following conventional specification (see Oliner et al, 1995; IMF, 2015):

$$
\ln N P F I_{t}=\alpha+\sum_{i=1}^{N} \beta_{i} \Delta \ln K_{t-i}^{\star}+\gamma \ln K_{t-1}+\epsilon_{t},
$$


i.e., nonresidential private fixed investment at time $t, N P F I_{t}$, is a function of the change in the desired (real) capital stock, $\Delta K_{t}^{*}$, associated with NPFI, which is proportional to the change in output, i.e., $\Delta K_{t}^{*}=\varphi \delta Y_{t}$, with $\$ \mathrm{~N} \$=12$ quarters (a common choice). The contemporaneous value is dropped to alleviate problems of reverse causality, and the equation is normalized with $K_{t-1}$ to address potential nonstationarity. The Newey-West procedure with automatic bandwidth selection is applied to coefficient estimates. The regression coefficients are provided in Annex Table 1.

Figure 8: Equipment, Structures, and IP (2015-2017), log index
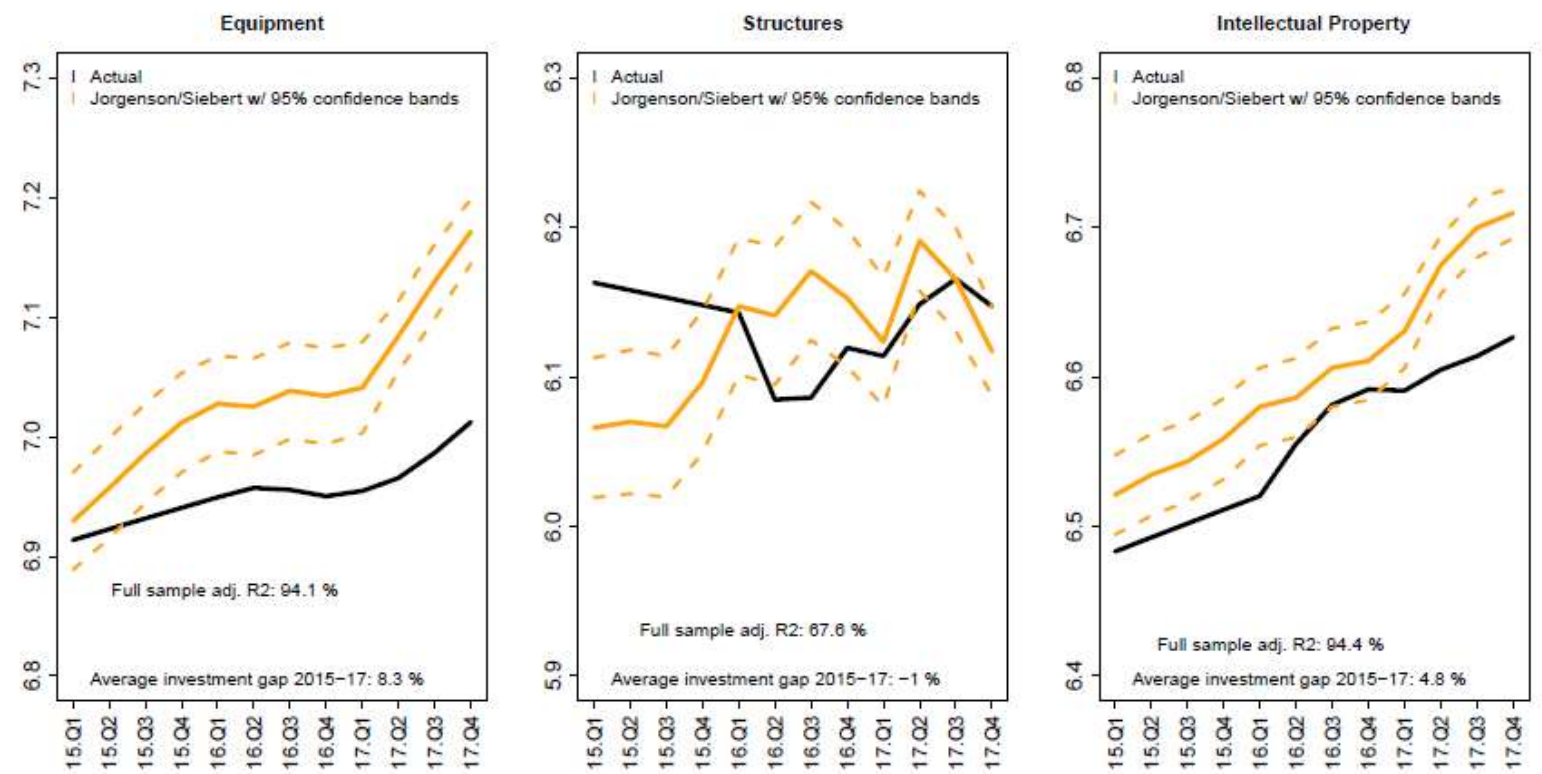

Source: BEA. Author's estimations.

In line with other empirical studies of U.S. business investment, aggregate demand growth explains 97 percent of the variation in NPFI. The Jorgenson and Siebert accelerator model suggests that the substantial drop in business investment during the initial stages of the GFC was quite in line with weak aggregate demand growth (Figure 7). In the aftermath of the crisis, however, the pickup in output growth suggested stronger growth in business investment than was actually observed. Especially during 2015-2016, investment surprised on the downside (middle chart). The investment gap (the difference between projected and actual business investment) averaged 4.1 percent over the three-year period 2015-2018. Even in 2017, when business investment returned to normal, there was still a meaningful investment gap.

Figure 8 disaggregates NPFI into its components. The lion's share of the investment gap was due to weak investment in equipment, where the average investment gap during 2015-2017 was around 8 percent. Investment in structures appears to have been in line with aggregate demand growth and, generally, follows more erratic patterns which are not particularly well explained by the basic accelerator model (with an $\mathrm{R}^{2}$ of only 68 percent). For IP, the accelerator model identifies an investment gap of around 5 percent on average. 
The relative price of investment goods (approximated by the relationship between investment and consumption deflators) has fallen steadily, especially over the last two decades (Figure 9, left chart), indicating that technological progress has considerably decreased the price of investment goods. ${ }^{4}$ Changes in the composition of business investment, as already shown in Figures 3 and 4, support the notion that business investment has turned more towards shorterlived equipment and IP, with faster depreciation (Figure 9, right chart), while the share of longer-lived capital stock in form of structures has lost importance.

\section{Figure 9: Relative Price of Investment, and Depreciation of Capital Stock, percent}
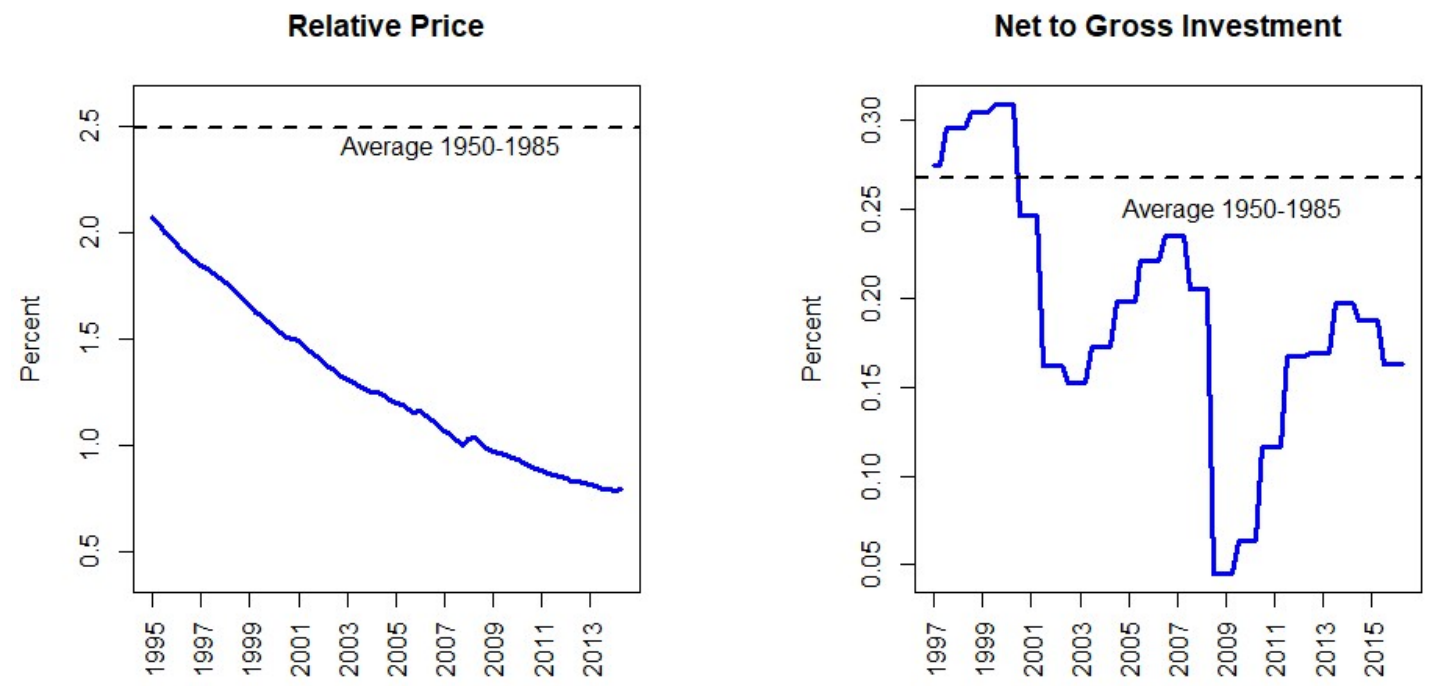

Source: BEA, Federal Reserve. Author's calculations.

When oil prices dropped dramatically, the oil and gas sector in the U.S. was hit hard (Figure 10). Annual oil and gas investment dropped from its 2014 peak of almost USD 200 million to considerably below USD 100 million, and companies lowered their capital expenditures by about 40 percent. For the first time in two years, 2016Q4 saw a stabilization if investment volumes. During 2015-2016, the leverage of exploration firms skyrocketed from a little over 20 percent to as high as 60 percent, and even in 2017 leverage remained elevated. At the same time, volatility of Oil and gas ETFs went up from 15 to almost 40 index points.

\section{B. Forward-looking Accelerator Model}

In practice, there is typically a lag between the time investment decisions are taken and when investment shows up in actual data. Hence, analyzing expectations of future growth can be useful. In equation (1), actual GDP growth is replaced by the consensus one-year ahead GDP forecast, $E\left[y_{t+4}\right]$ :

\footnotetext{
${ }^{4}$ In addition to technological progress, indirect factors like increased trade openness also contributed to the change in relative prices.
} 


$$
\ln I_{t}=\alpha+\ln E\left[y_{t+4}\right]+\gamma \ln K_{t-1}+\epsilon_{t} .
$$

The output of this forward-looking accelerator model is illustrated in Fig. 11 for equipment investment. Results suggest that investment was well in line with one-year ahead growth expectations. Using growth expectations instead of actual GDP growth reduces by about half the 2015-2016 investment gap estimated from the Jorgenson and Siebert model in equation (1). Hence, actual investment has been consistent with demand growth expectations. Although the forward-looking model explains business investment better during 2015-2017, the richer specification of the Jorgenson/Siebert model (12 lags of output growth and the lagged capital stock) leads to a generally better fit over the estimation window.

\section{Figure 10: U.S. Energy Sector: Market Leverage, ETF Volatility, and Investment}
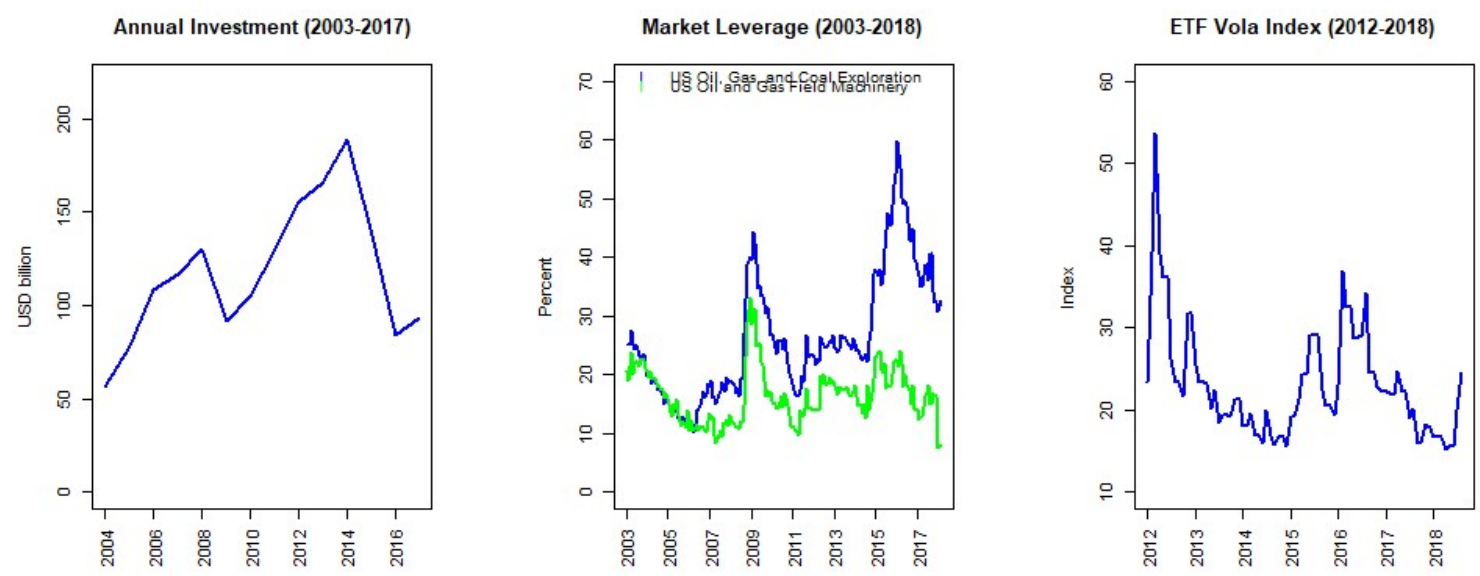

Source: Moody's Credit Edge, Federal Reserve, S\&P. Author's illustration.

Figure 11: Forward-looking Accelerator for Equipment (1908-2017)
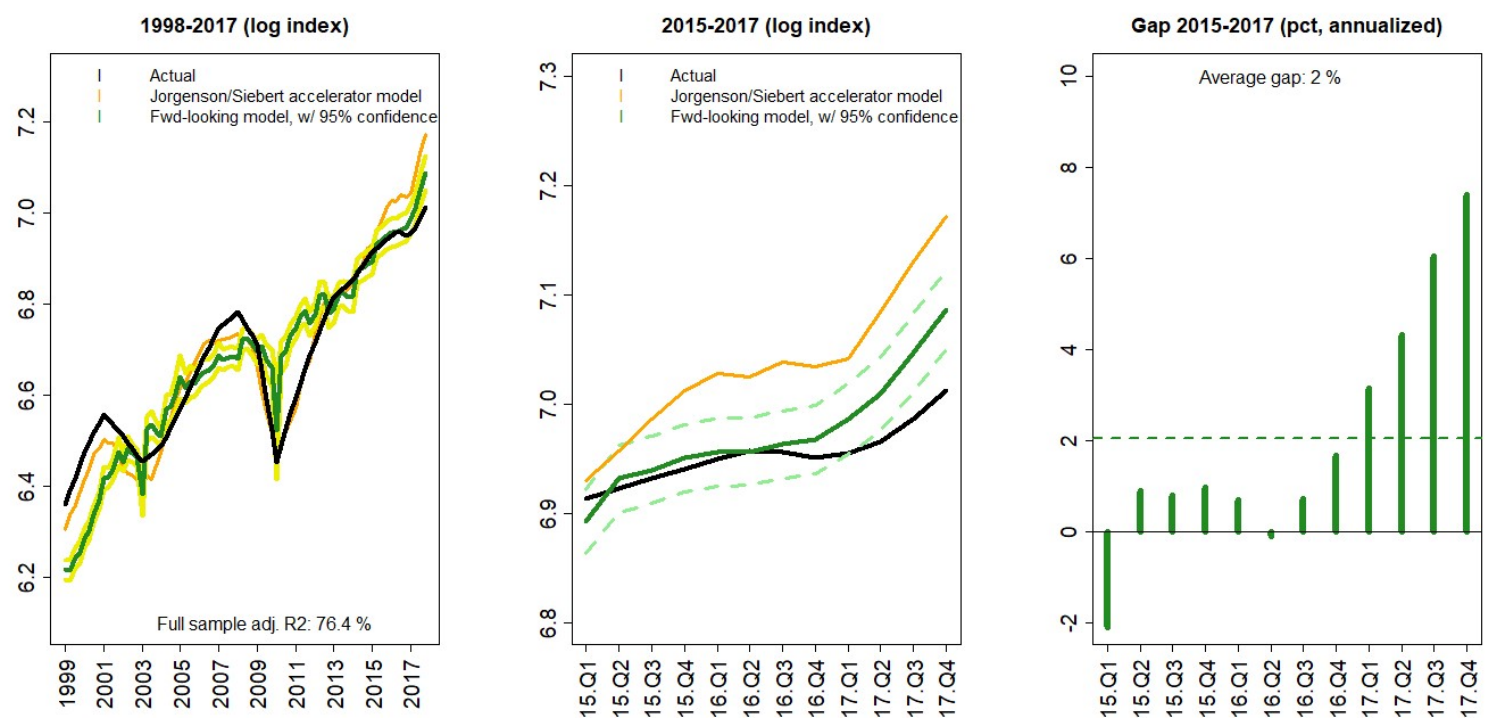

Source: BEA, Federal Reserve Bank of Philadelphia. Author's estimation. 


\section{Accelerator Models Augmented with Macroeconomic Variables}

Next, the model in equation (1) is augmented with $\$ \mathrm{j}=1 \ldots \mathrm{J} \$$ macroeconomic variables $\beta_{j} X_{j, t-h}^{*}$ with dynamic lag $h$

$$
\ln I_{t}=\alpha+\sum_{i=1}^{N} \beta_{i} \Delta \ln K_{t-i}^{\star}+\gamma \ln K_{t-1}+\beta_{j} X_{j, t-h}^{*}+\epsilon_{t} .
$$

\section{Figure 12: Accelerator Models with Macro Factors (log index)}
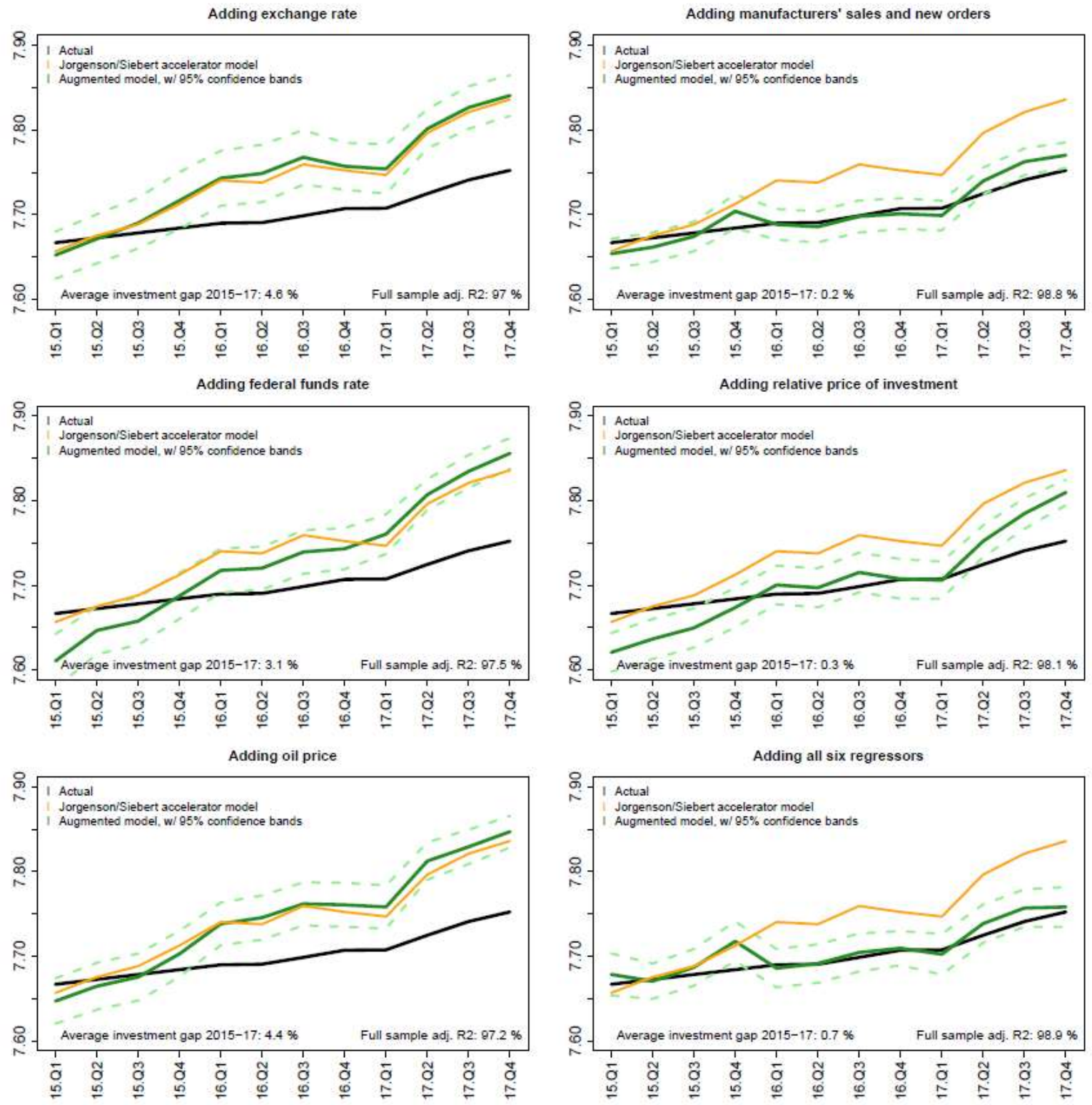

Source: BEA, Federal Reserve. Author's estimation. 
Figure 12 shows the output for the Jorgenson and Siebert model if individual macroeconomic variables are added. While including the exchange rate or the oil price does not improve the fit of the Jorgenson and Siebert model, the variables "manufacturing and trade sales" and "manufacturers' new orders" do. Both variables aim at capturing demand growth. The investment gap basically becomes zero, and the augmented model generally has higher explanatory power than the basic Jorgenson and Siebert model (adjusted $\mathrm{R}^{2}$ is 2 percentage points higher). Augmenting the Jorgenson and Siebert model with the relative price of investment reduces dramatically the investment gap estimated from the model in equation (1). The falling relative price of investment explains more than 1 additional percent of the variation in NPFI. Both the level of interest rates, as measured by the federal funds rate, and the oil price level marginally improve the explanatory power of the accelerator model but fail to shed more light on the more recent behavior of NPFI.

\section{FinANCIAL FACTORS}

Financial conditions can play a role in understanding temporal variation in investment growth. Since not all investment can be financed internally through retained earnings, the supply and affordability of debt market financing is an important precondition for investment. Tight financial conditions would, therefore, reduce investment growth as some projects economically do not make sense if the financing cost exceeds the expected return on investment. Separately, firms may decide to use retained earnings for activities other than capital expenditure, like share buybacks, dividend increases, or mergers and acquisitions. The increased use of these measures has sometimes been alleged of crowding out capital expenditure.

\section{A. Strategic Decision Making by Firm Executives}

Starting at the end of the recession, corporate profits increased sharply and firms also began to retain a larger share of their earnings. While this should have stimulated business investment through reinvestment of profits, executives increasingly decided to boost shareholder returns by increasing dividend payout and support share prices (and, thus, management compensation) through buybacks. Post-GFC, net payouts have averaged 2.7 percent of total assets, an increase of 50 percent compared to the pre-GFC period (Figure 13).

Buyback activities are a relatively recent phenomenon. Until the early 1980s, buybacks were mainly seen as instruments for market manipulation. ${ }^{5}$ With the Securities and Exchange Commission loosening the regulation ${ }^{6}$ of buybacks, the popularity of share repurchases increased enormously, especially from the 1990s when stock options became a common compensation instrument. The evidence of buybacks boosting subsequent profits is mixed and largely depends on the time horizon and market timing. But a recent study by S\&P Capital

\footnotetext{
${ }^{5}$ Share repurchases cause a reduction in the number of shares in issue, and boost earnings per share (EPS) or can stabilize the share price in situations where employees and executives exercise their sell options.

${ }^{6}$ Securities Exchange Act, Rule 10b-18.
} 
(2014) found that US firms that announced buybacks significantly outperformed their market, sector, and size, both statistically and economically over time horizons of one month and one year. However, this does not necessarily have implications for capital expenditure.

Figure 13: Real Investment vs. Financial Measures (1981-2016)

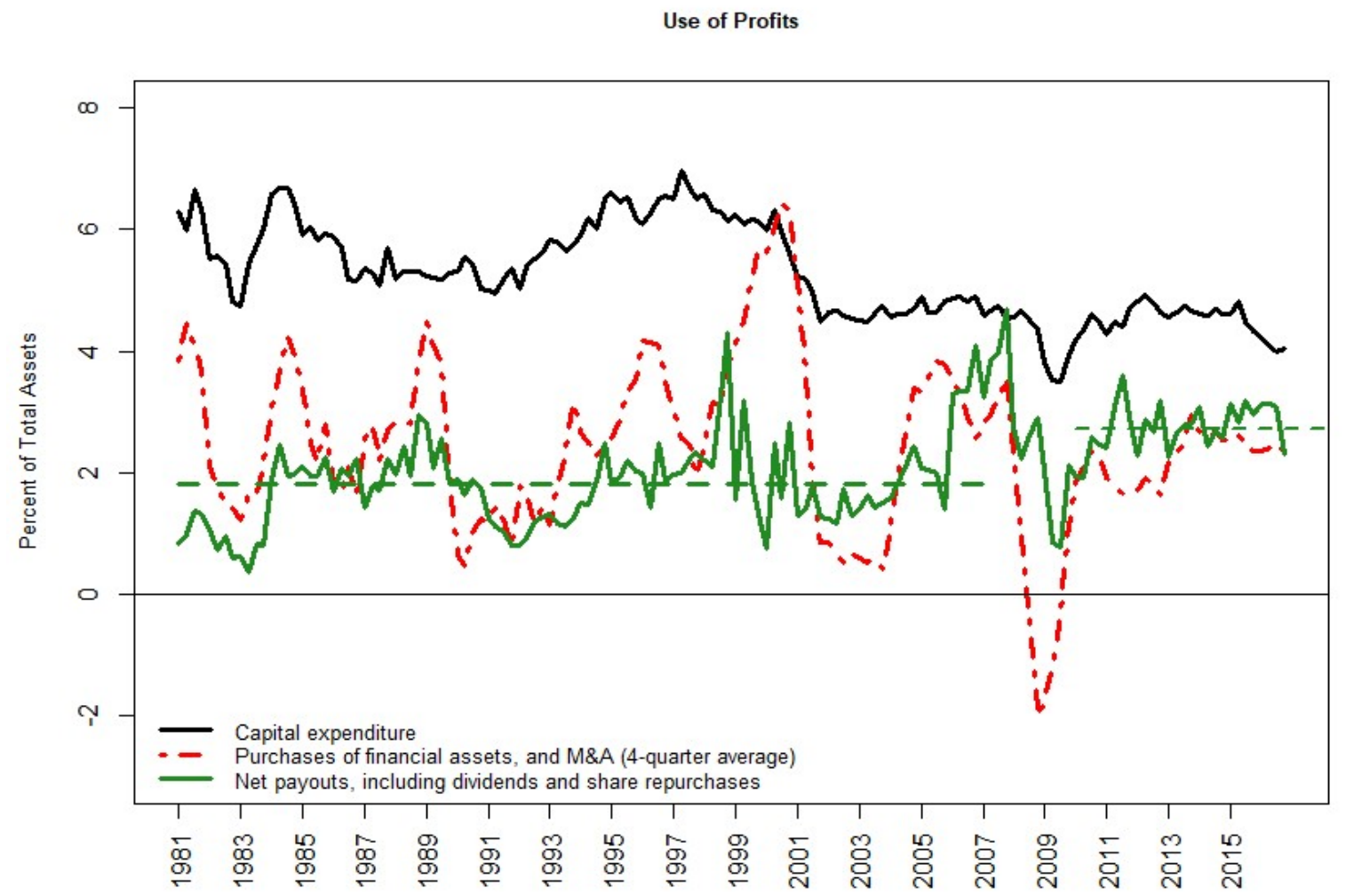

Source: IMF, Federal Reserve. Author's illustration.

It may appear that increased buyback activity and larger dividends payouts crowded out real investment into productive capabilities of nonfinancial firms. Lazonik (2014) argues that the "financialization of nonfinancial business" causes a reduction in nonresidential business investment and, consequently, productive capabilities, with long-term implications for firm competitiveness. Following this argument, misaligned incentive structures for firm management, which promote short-term profit over longer-term value creation, need to take part of the blame for the weakness in investment. On the other hand, Gruber and Kamin (2017) find no evidence in cross-country aggregate data for shareholder payouts crowding out business investment: Economies that have experienced larger investment gaps have not necessarily seen increases in share buybacks and/or dividend payments, indicating that these two developments are unrelated, and that buybacks would have increased irrespective of the behavior of capital expenditure (Figure 14). 
Figure 14: International Perspective

Investment vs. Buybacks and Dividends

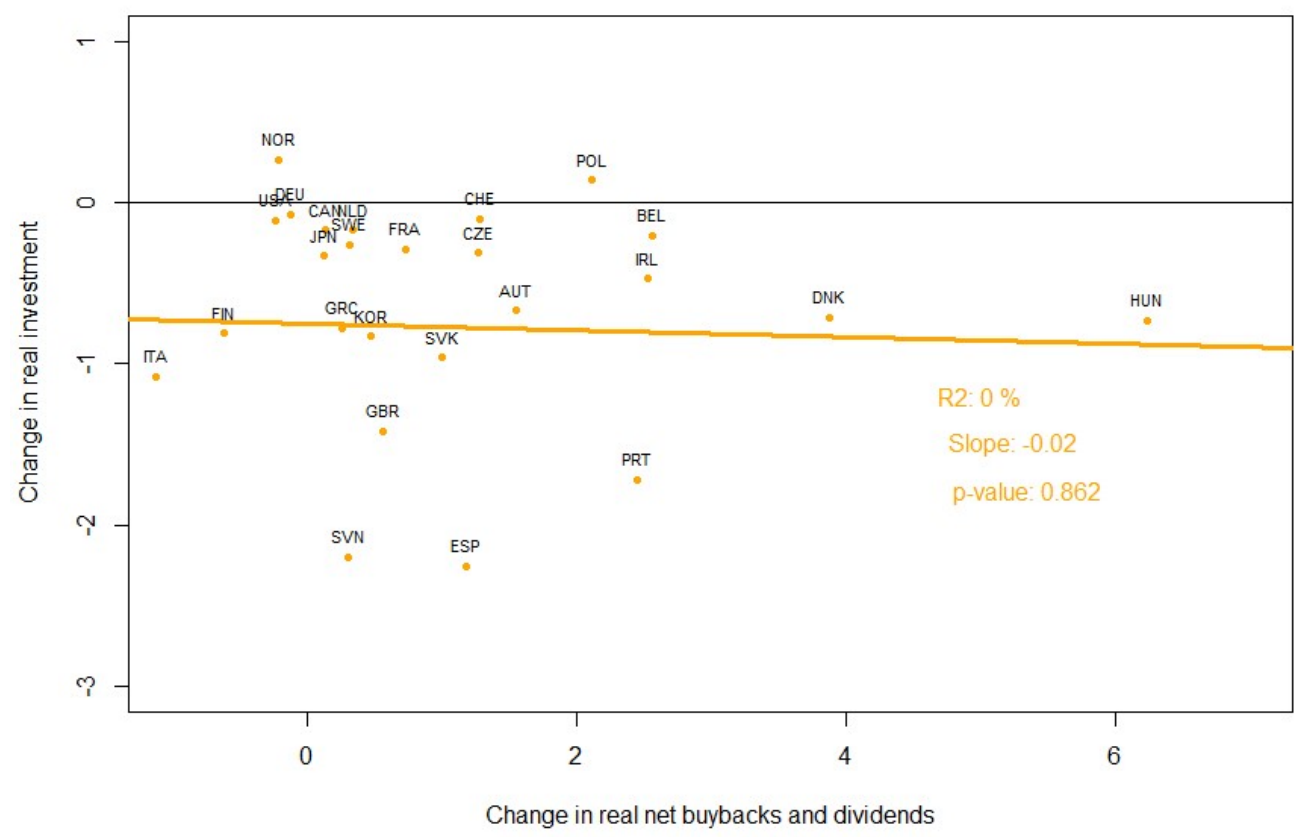

Source: Federal Reserve, Gruber and Kamin (2017). Author's calculations.

Figure 15: Demand for Credit, Lending Standards, and Corporate Funding Costs
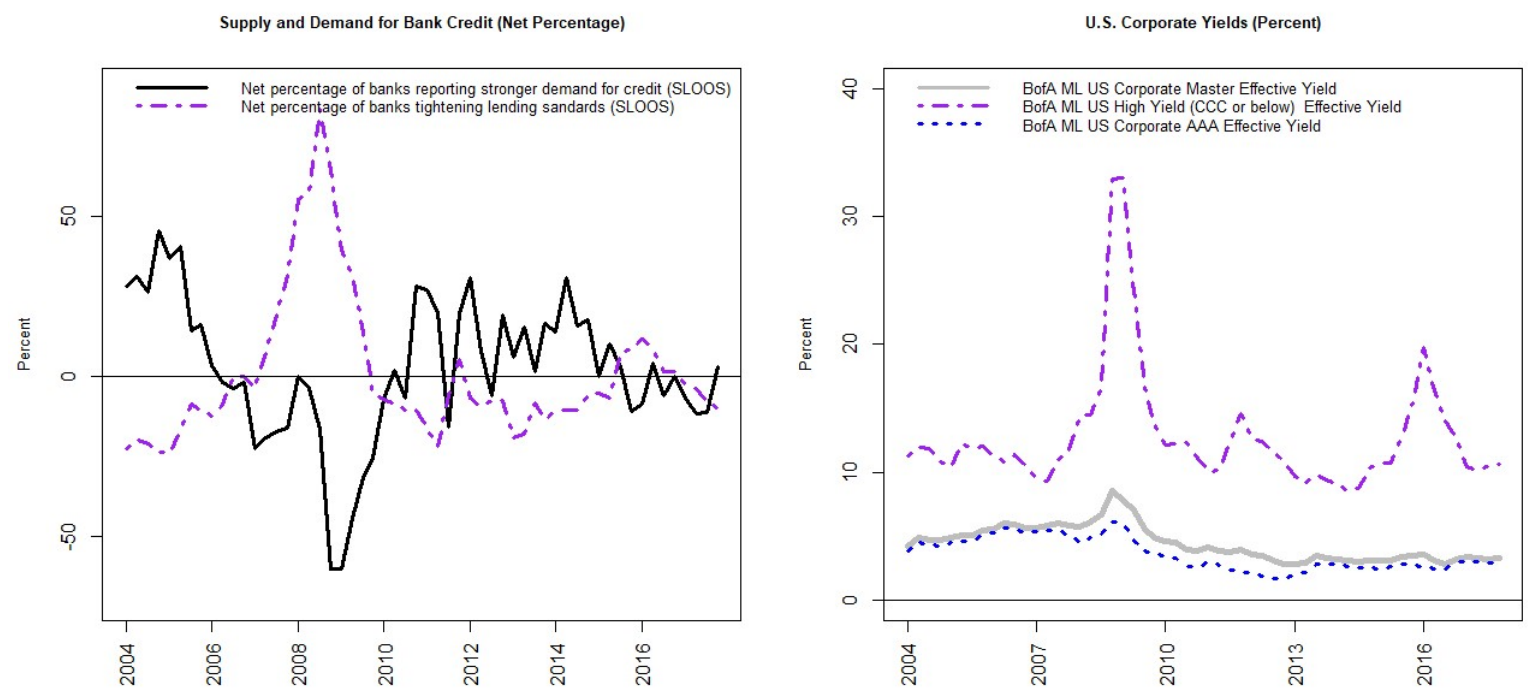

Source: Bank of America Merrill Lynch, Federal Reserve. Author's illustration. 


\section{B. Funding Availability and Cost}

Another argument that has been made was that firms may have experienced difficulties in accessing funding at reasonable cost, and that this has contributed to weak investment growth. However, as can be seen in Figure 14, bank lending standards in the aftermath of the crisis have been very loose by historical standards, and a (net) tightening of lending standards was reported by senior loan officers only during 2015-2016. Similarly, U.S. corporates on average enjoyed favorable debt market conditions (right chart), especially those with strong credit ratings (the dotted blue line gives the yields for AAA-rated firms). High Yield corporate bonds, which were to a considerable extent issued by firms in the U.S. oil and gas sector, have however seen a sharp spike in yields and, hence, firms' debt financing cost.

\section{Accelerator Models Augmented with Financial Variables}

Augmenting the Jorgenson and Siebert accelerator model with a broad financial conditions index neither results in a better model nor helps explain business investment during 2015-2017 (Figure 16). Hence, these is no evidence that financial conditions would generally drive business investment in the U.S. economy. And also during the more recent past, the National Financial Conditions index does not help explain the behavior of NPFI.

Particularly since Cochrane's (1991) paper, which argued that investment growth should be closely linked to expected equity returns, the relationship between investment, stock prices, and past profits has been subject to intensive discussion. Recent papers, including Bloom (2009), Gilchrist and Zakrajsek (2012), and Kothari and others (2017), predominately find that expected investment is closely related to volatility in stock prices. But evidence of strong correlation with equity returns has been rather mixed. The augmented accelerator models suggest that adding equity market valuations to the accelerator model can improve the fit of the accelerator model $\mathrm{R}^{2}$ above 98 percent) and further explain around a quarter of the recent investment gap (top left chart). The VIX, a measure of implied equity market volatility (top right chart), does not contribute to a better fit of the accelerator model. While aggregate corporate profits generally improve the model, it does not seem that profits can explain NPFI during the past three years (middle left chart).

Looking at bank credit supply and demand for bank credit (middle right chart), as measured by the Senior Loan Officers Opinion Survey on Bank Lending Practices, nothing suggests that tight lending conditions significantly impacted growth in business investment. There was some tightening during 2015-2017, as depicted in Figure 15, which also shows up in the augmented accelerator model. But, again, tight lending conditions or weak demand for bank credit do not explain much of the recent investment behavior. Results further suggest that debt market funding was not issue for the average U.S. firm but for some high yield companies, which saw their yields increase substantially during the crisis in the oil and gas sector. By mid-2017, yields of High Yield bonds came down to normal levels of around 10 percent. The minor tightening of lending standards during 2015-2016 was unlikely to have held back investment growth. This is also in line with the Banerjee et al (2015) study of post-crisis investment performance. 
Figure 16: Accelerator Models with Financial Factors
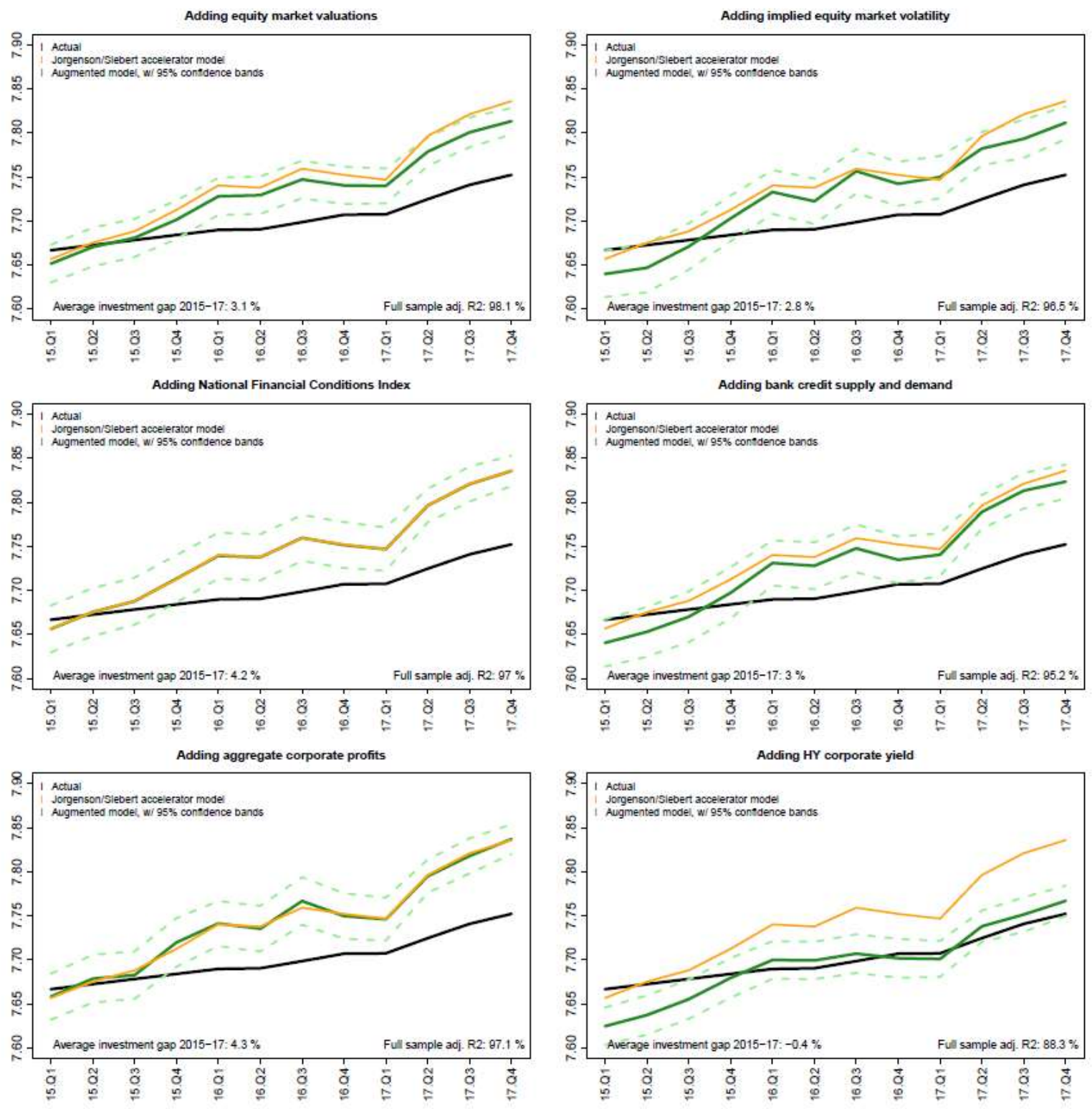

Source: BEA, Federal Reserve. Author's estimation.

\section{Political Economy Factors}

Political and economic policy uncertainty adversely impacts investment. Bernanke (1983) provided some of the first theoretical work that assessed the impact of uncertainty on investment and growth. He argued that high uncertainty induces firms to delay investment (especially when it is irreversible) and hiring, but that investment activity picks up once uncertainty reduces. There are countless empirical studies that analyze the relationship 
between financial market volatility and investment in productive capabilities. ${ }^{7}$ Different from market fluctuations as a source of uncertainty, there is a more recent strand in the literature that measures economic policy uncertainty using newspaper text search (Bloom, 2009; Baker and others, 2016). Using as well semantic search strategies, Azzimonti (2017) argues that the more recent weakness in fixed investment in the U.S. was caused partly by heightened partisan policy disputes and Congressional gridlock as fiscal policy uncertainty increased. She shows that partisan conflict is linked to lower investment growth and that this particularly affects firms that rely on government spending (e.g., contractors, defense industry) or actively engage in political campaigns.

\section{Figure 17: Accelerator Models with Political Economy Factors}
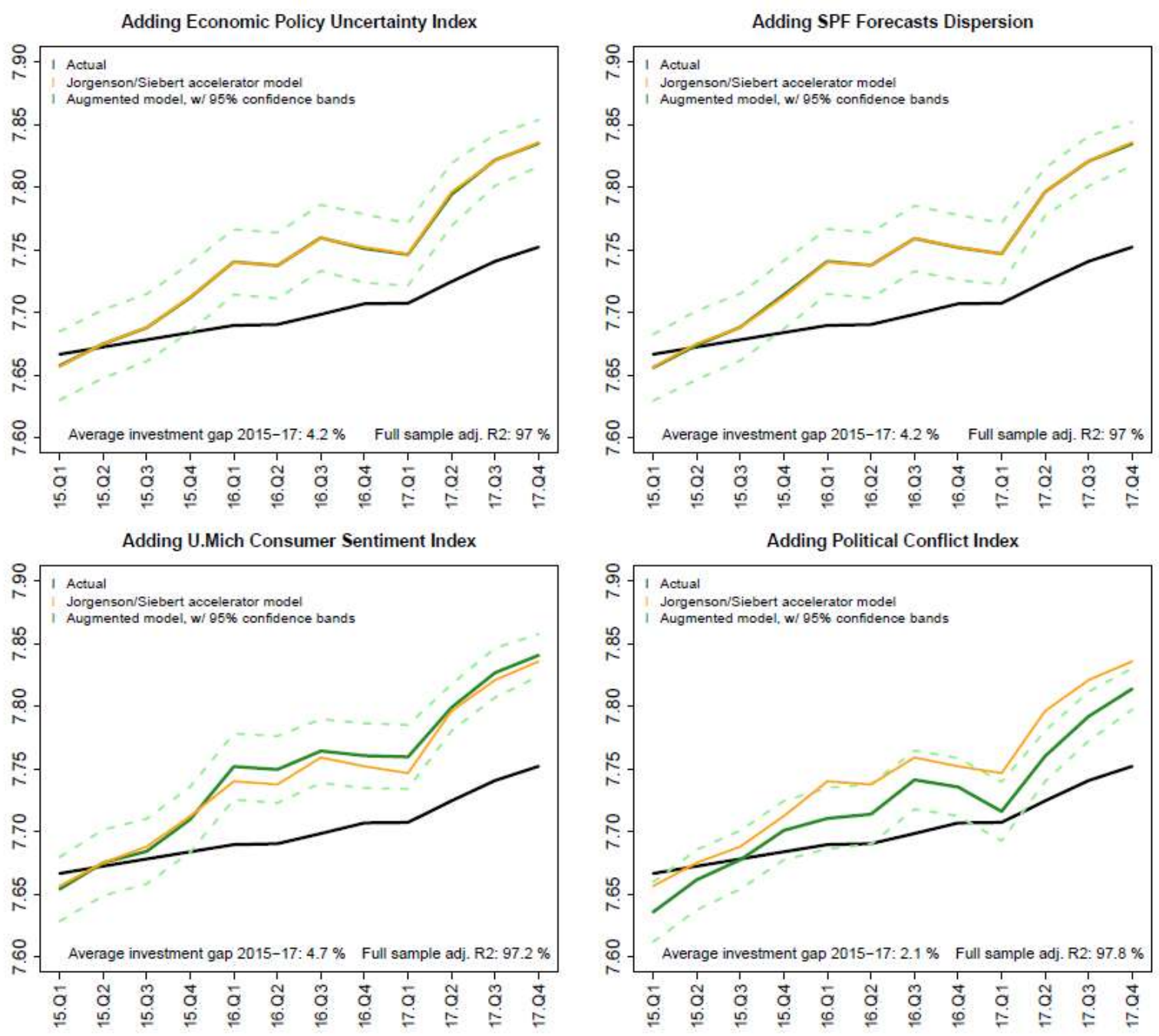

Source: Azzimonti (2017), BEA, Federal Reserve, SPF. Author's estimation.

\footnotetext{
${ }^{7}$ For a literature review, see Bloom (2014).
} 
Adding different measures of uncertainty about future economic policies or the dispersion of growth forecasts does not help explain the temporal variation in NPFI. Figure 17 shows that measures of uncertainty do not improve the explanatory power of the basic accelerator model (top charts). The Jorgenson and Siebert accelerator model augmented with the Economic Policy Uncertainty Index (Bloom, 2009; Baker and others, 2016) does not perform better than the basic model, neither in general nor specifically in during 2015-2017. Likewise, the dispersion of individual projections in the Survey of Professional Forecasters (SPF), shown in the top right chart, does not add information to a model that solely uses acceleration in aggregate demand growth. Adding consumer sentiment marginally improves the fit of the model. Adding consumer sentiment marginally improves the fit of the model.

\section{Bayesian Model AVERaging}

Obviously, there is an infinite number of models that can describe the behavior of time series. And it is not straightforward how to select the best model from the set of all possible models. Even Best Subset selection, which identifies the best model for each number of regressors using certain information criteria (BIC, AIC, etc), typically identifies one single model as the "best" model. However, relying on one single specification, even if it is the "best" one, induces considerable model risk.

Bayesian Model Averaging (BMA) is an application of Bayesian inference to model selection, combined estimation and prediction that yields a straightforward model choice criteria and less risky predictions (see, for instance, Leamer, 1978). The posterior model probabilities can be applied as a model selection criterium, with the most likely models being selected. The posterior distribution, $P(\Psi)$, given data $D$, is the average of the posterior distributions of each relevant model, weighted by their respective posterior probability:

$$
\left.P(\Psi \mid D)=\sum_{k=1}^{K} P\left(\Psi \mid M_{k}, D\right) P\left(M_{k}\right) \mid D\right)
$$

The posterior probability for a specific model $M_{k}$ is then

$$
P\left(M_{k} \mid D\right)=\frac{P\left(D \mid M_{k}\right) P\left(M_{k}\right)}{\sum_{l=1}^{K} P\left(D \mid M_{l}\right) P\left(M_{l}\right)}
$$

with

$$
P\left(D \mid M_{k}\right) P\left(M_{k}\right)=\int P\left(D \mid \Phi_{k}, M_{k}\right) P\left(\Phi_{k} \mid M_{k}\right) d \Phi_{k}
$$

The posterior mean and variance of $\Psi$ are 


$$
\begin{aligned}
E[\Psi \mid D] & =\sum_{k=0}^{K} \Psi_{k} P\left(\hat{M}_{k} \mid D\right) \\
\operatorname{Var}[\Psi \mid D] & =\sum_{k=0}^{K}\left(\operatorname{Var}\left[\Psi \mid D, M_{k}\right]+\left(E\left[\Psi \mid D, M_{k}\right]\right)^{2}\right) P\left(M_{k} \mid D\right)-E[\Psi \mid D]^{2}
\end{aligned}
$$

With BMA, one can directly combine models to obtain combined parameter estimates or predictions, which leads to predictions that are less subject to model risk under a logarithmic scoring rule (see Madigan and Raftery, 1994) than using just one single model. Hence, BMA accounts for model uncertainty inherent in the variable selection problem by averaging over the best models in each model class according to approximate posterior model probability (Fragoso et al, 2018).

\section{Figure 18: Bayesian Model Average, Non-oil: Predictors}

FX rate, lag 3
Oil price, lag 3
Equity valuations, lag3
Equity returns, lag 3
New orders, lag 3
Sales, lag 3
$\Delta$ new orders, lag 3
Rel. Price, lag 4
Fed Funds Rate, lag 4
Equity returns, lag 4
Equity returns, lag 5
$\Delta$ profits, lag 5
BAA - 10Y, lag 5
CPI gap, lag 5
Fed Funds Rate, lag 5
Profits, lag 3
Fed Funds Rate, lag 4
Cons sent., lag 5
$\Delta$ profits, lag 4
$\Delta$ Fed Funds Rate, lag 4
Profits, lag 4
In SPF dispersion, lag 4
Polit. Conflict Idx, lag 5
Profits, lag 5
PCE growth, lag 4
SPF dispersion, lag 5
Polit. Conflict Idx, lag 3
BAA - 10Y, lag 4
PCE growth, lag 5
SPF dispersion, lag 5

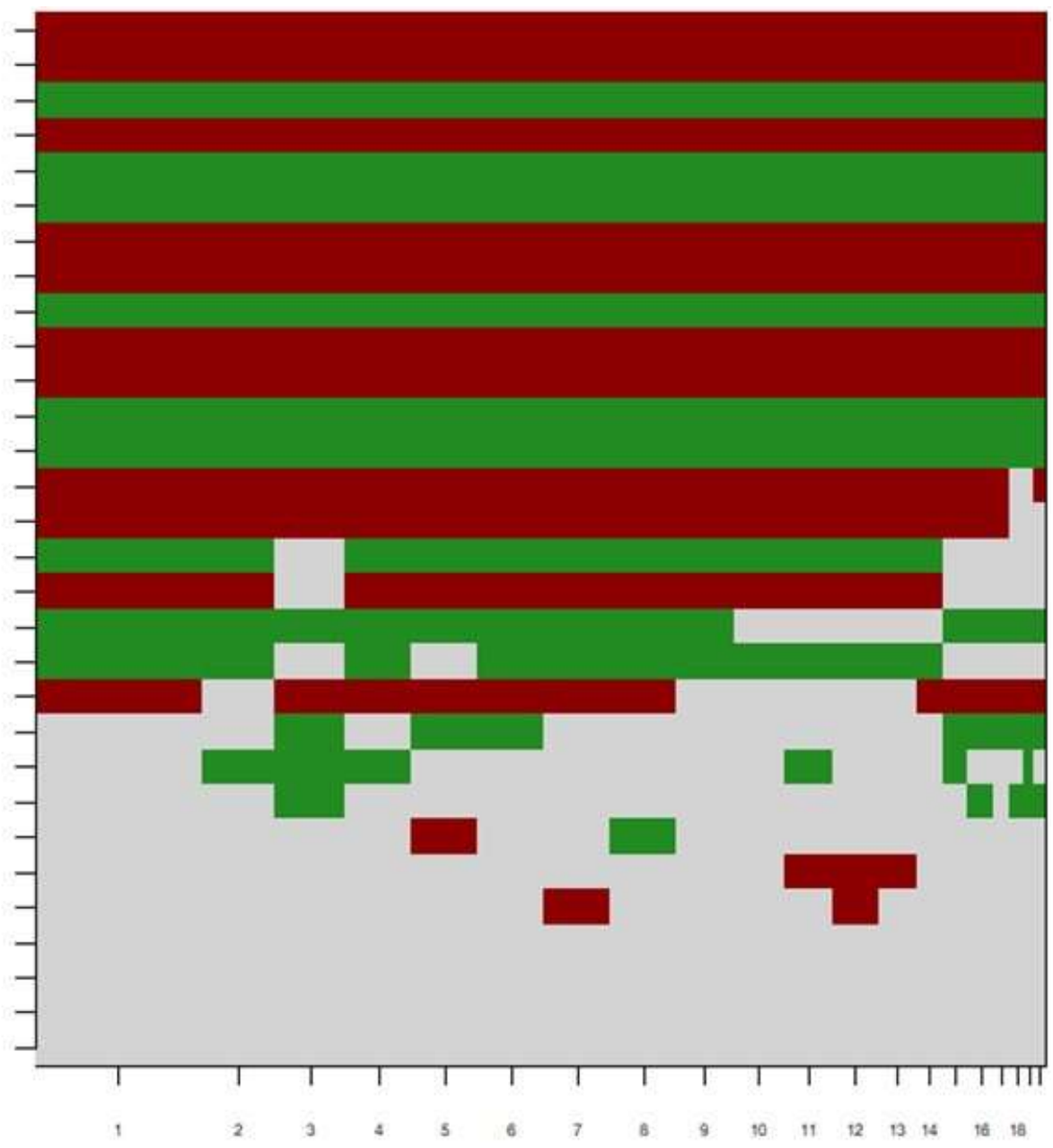

The set of models is estimated over the period 1983Q4-2014Q4, with out-of-sample forecasts stretching from 2015.Q1 to 2017.Q4 (12 quarters). Due to its idiosyncratic character, oil and 
gas investment is excluded from aggerate business investment. Specifically, private fixed investment in oil and gas extraction equipment, structures and IP is subtracted from NPFI, resulting in non-oil and gas NPFI.

Table 1: Bayesian Model Averaging, Non-oil: Posterior Probabilities and Means

\begin{tabular}{|c|c|c|}
\hline & Posterior Prob & Posterior Mean \\
\hline Intercept & & -2.056 \\
\hline FX rate, lag 3 & 100 & -0.168 \\
\hline Oil price, lag 3 & 100 & -0.107 \\
\hline Equity valuations, lag3 & 100 & 0.217 \\
\hline Equity returns, lag 3 & 100 & -0.001 \\
\hline New orders, lag 3 & 100 & 0.116 \\
\hline Sales, lag 3 & 100 & 0.464 \\
\hline$\Delta$ new orders, lag 3 & 100 & -0.001 \\
\hline Polit. Conflict Idx, lag 3 & 0 & 0.000 \\
\hline Profits, lag 3 & 83 & 0.060 \\
\hline Rel. Price, lag 4 & 100 & -0.222 \\
\hline Fed Funds Rate, lag 4 & 100 & 0.026 \\
\hline$\Delta$ Fed Funds Rate, lag 4 & 83 & -0.000 \\
\hline PCE growth, lag 4 & 13 & -0.001 \\
\hline Equity returns, lag 4 & 100 & -0.001 \\
\hline SPF dispersion, lag 4 & 29 & 0.000 \\
\hline Profits, lag 4 & 30 & 0.026 \\
\hline$\Delta$ profits, lag 4 & 76 & 0.001 \\
\hline $\mathrm{BAA}-10 \mathrm{Y}$, lag 4 & 0 & 0.000 \\
\hline CPI gap, lag 5 & 98 & -0.008 \\
\hline Cons sent., lag 5 & 79 & 0.041 \\
\hline Fed Funds Rate, lag 5 & 96 & -0.014 \\
\hline$\Delta$ Fed Funds Rate, lag 5 & 69 & -0.000 \\
\hline PCE growth, lag 5 & 0 & 0.000 \\
\hline Equity returns, lag 5 & 100 & -0.001 \\
\hline Polit. Conflict Idx, lag 5 & 13 & 0.000 \\
\hline SPF dispersion, lag 5 & 0 & 0.000 \\
\hline SPF dispersion, lag 5 & 11 & -0.000 \\
\hline Profits, lag 5 & 13 & -0.002 \\
\hline$\Delta$ profits, lag 5 & 100 & 0.001 \\
\hline $\mathrm{BAA}-10 \mathrm{Y}, \operatorname{lag} 5$ & 100 & 0.021 \\
\hline
\end{tabular}

Source: Author's estimation.

Figure 18 illustrates which explanatory variables have the highest probability of being included in each model, based on the respective Bayesian information criteria. ${ }^{8}$ The 14 models with the lowest BIC essentially include the same explanatory variables. Red colored cells indicate a negative coefficient, while green cells show positive coefficients (gray fields mean a candidate variable is not included in the model). As that illustration does not provide information on the exact posterior probability of a variable or the size of its (mean) posterior coefficient, Table 1 lists these details for each variable shown in Figure 18.

\footnotetext{
${ }^{8}$ This figure was produced using an R code provided in the package $\boldsymbol{B} \boldsymbol{M} \boldsymbol{A}$ (Raftery et al, 2018).
} 
The results confirm the findings from the previous sections: Among macroeconomic variables, a falling relative price of investment (Rel. Price) positively impacts business investment. Furthermore, the oil price (Oil price) and the exchange rate ( $F X$ rate) have posterior probabilities of 100 percent, and negative coefficients. Hence, a strong dollar and high oil price levels tend to have an adverse effect on NPFI. Furthermore, total real manufacturing and trade sales (Sales) and manufacturers' new orders (New orders) also have a significant and large impact on business investment, as these two variables proxy future aggregate demand. Higher levels of the Fed Funds Rate are characteristic for late cycle expansions, reflecting strong aggregate demand growth. Rate hikes (changes in DFF; $\Delta$ Fed Funds Rate), however, seem to have a negative impact, likely because they indicate higher future debt financing cost, which reduce firms' net profits and, thus, available internal funding for investment projects.

Figure 19: Bayesian Model Average: Non-oil (2015-2017)
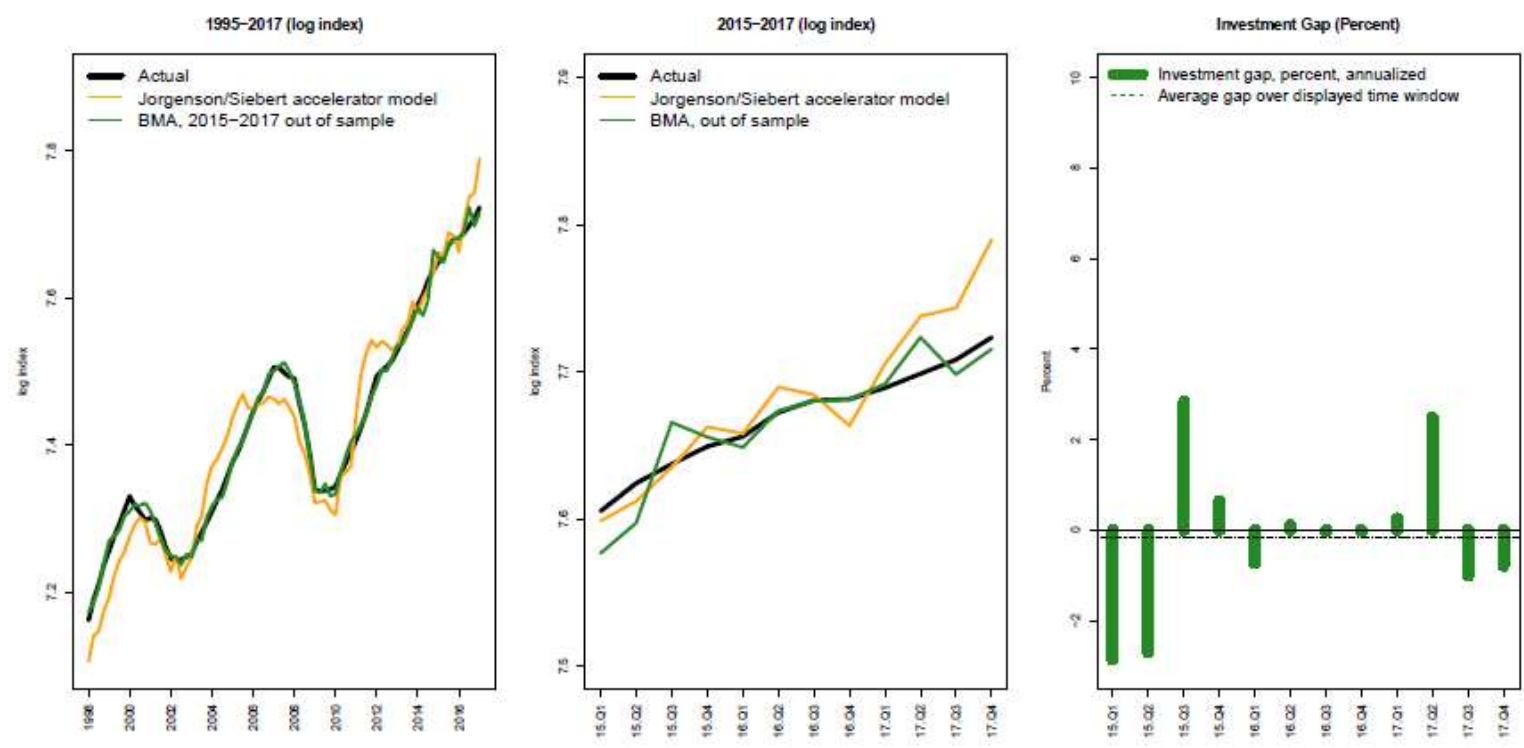

Source: BEA. Author's estimation.

Rich equity valuations (measured by the broad Russell 1000 Total Return Index; Equity valuations) and high firm profits (Profits) predict stronger future growth in business investment, which is in line with many other empirical studies. Corporate bond spreads (BAA$10 Y$ ), however, do not have an economically significant influence on business investment. The other financial factors that have been alleged as influencing investment (equity market volatility, bank credit supply, demand for bank credit, or high yield spreads) are neither identified as relevant drivers nor economically significant, and do not systematically drive business investment in the U.S. economy.

Consistent with the findings from the augmented accelerator models, there is no evidence of economic policy uncertainty being a relevant stand-alone factor for business investment decisions, or that a high growth forecast uncertainty, measured by a wider dispersion of individual growth forecasts from the SPF (SPF dispersion), are associated with weak business 
investment. The analysis further suggests that, economically, political conflict (Polit. Conflict $I d x$ ) is not a key determinant of business investment, at least not in combination with other, more traditional macroeconomic and financial factors. However, positive sentiment (Cons. sent.) supports the expansion of business investment; this may again just point to expectations of accelerating future aggregate demand.

Figure 19 shows for NPFI excluding oil and gas the out-of-sample projection from the BMA approach. The model essentially explains the entirety of the investment behavior during 20152017 (middle chart), with an average investment gap of zero (right chart). Special factors, like policy or forecast uncertainty, financial frictions, and political conflict play only limited or no roles. Hence, U.S. business investment has been well in line with what aggregate demand growth, corporate profits, and equity valuations suggested. Going forward, the projected acceleration of aggregate demand growth - in combination with rich equity valuations and high past corporate profits-will induce an increase in NPFI activity. 


\section{REFERENCES}

Arif, Salman and Charles M.C. Lee. 2014. "Aggregate Investment and Investor Sentiment." The Review of Financial Studies, Vol. 27 (11), p. 3241-3279.

Azzimonti, Marina. 2018. "Partisan Conflict and Private Investment." Journal of Monetary Economics, Vol. 23, p. 114-131.

Baker, Scott and Nicholas Bloom. 2013. "Does Uncertainty Reduce Growth? Using Disasters as Natural Experiments." NBER Working Papers, No. 19475, NBER, Inc.

Baker, Scott, Nicholas Bloom, and Steven Davis. 2016. "Measuring Economic Policy Uncertainty." Quarterly Journal of Economics, Vol 131 (4), p. 1593-1636.

Banerjee, Ryan, Jonathan Kearns and Marco Lombardi, 2015. "(Why) Is Investment Weak?" in: BIS Quarterly Review, March 2015, Bank for International Settlements (BIS).

Bernanke, Ben. 1983. "Irreversibility, Uncertainty and Cyclical Investment." Quarterly Journal of Economics, Vol. 97 (1983), p. 85-106.

Bloom, Nicholas. 2009. "The Impact of Uncertainty Shocks." Econometrica, Vol. 77, p. 623685.

Bloom, Nicholas. 2014. "Fluctuations in Uncertainty." Journal of Economic Perspectives, Vol. 28 (2), p. 153-176.

Bureau of Economic Analysis (BEA). 2017. "Private Fixed Investment." In: NIPA Handbook, Chapter 6.

Campello, Murillo, John Graham, and Campbell Harvey. 2010. "The Real Effects of Financial Constraints: Evidence from a Financial Crisis." Journal of Financial Economics, Vol. 97 (3), p. 470-487.

Cochrane, John. 1991. "Production-Based Asset Pricing and the Link Between Stock Returns and Economic Fluctuations." Journal of Finance, Vol. 46 (1), p. 209-237.

Fragoso, Tiago, Wesley Bertoli, and Francisco Louzada. 2017. "Bayesian Model Averaging: A Systematic Review and Conceptual Classification." International Statistical Review, Vol. 86 (1), April 2018, p. 1-28.

Gilchrist, Simon and Egon Zakrajsek. 2012. "Credit Spreads and Business Cycle Fluctuations." American Economic Review, Vol. 102 (4), p. 1692-1720. 
Gilchrist, Simon, Jae W. Sim, and Egon Zakrajsek. 2014. "Uncertainty, Financial Frictions, and Investment Dynamics," NBER Working Paper No. 20038, 2014.

Gruber, Joseph and Steven Kamin (2017). "Corporate Buybacks and Capital Investment: An International Perspective," IFDP Notes 2017-04-11. Board of Governors of the Federal Reserve System (U.S.)

Gutierrez, German and Thomas Philippon. 2016. "Investment-Less Growth: An Empirical Investigation." NBER Working Paper 22897, December 2016.

IMF. 2015. "Private Investment: What's the Holdup?" In: IMF World Economic Outlook, April 2015.

Jorgenson, Dale. 1963. "Capital Theory and Investment Behavior." American Economic Review, 53 (2), p. 247-259.

Jorgenson, Dale and Calvin Siebert. 1968. "A Comparison of Alternative Theories of Corporate Investment Behavior." American Economic Review, Vol. 58 (4). p. 681712.

Kothari, S.P, Jonathan Lewellen and Jerold Warner. 2017/2014. "The Behavior of Aggregate Corporate Investment." MIT Sloan Research Paper No. 5112-14, Sloan School of Management, MIT, 2014. Updated version as of 2017.

Lazonik, William. 2014. "Profits Without Prosperity." In: Harvard Business Review, September 2014. URL: https://hbr.org/2014/09/profits-without-prosperity.

Leamer, 1978. "Specification Searches." New York: Wiley.

Madigan, David, and Adrian E. Raftery. 1994. "Model Selection and Accounting for Model Uncertainty in Graphical Models Using Occam's Window." Journal of the American Statistical Association, Vol. 89, p. 1535-46.

OECD. 2015. "Lifting Investment for Higher Sustainable Growth." In: OECD Economic Outlook, Vol. 2015/1, Chapter 3. OECD, Paris, 2015.

Oliner, Stephen, Glenn Rudebusch, and Daniel Sichel. 1995. "New and Old Models of Business Investment: A Comparison of Forecasting Performance." Journal of Money, Credit and Banking, Vol. 27, No. 3. 
Pinto, Eugenio and Stacey Tevlin. 2014. "Perspectives on the Recent Weakness in Investment." Federal Reserve Board of Governors, FEDS Notes, May 21, 2014.

Raftery, Adrian, Jennifer Hoeting, Chris Volinsky, Ian Painter, and Ka Yee Yeung. 2018. "Package BMA." Version 3.18.8, CRAN depository, March 22, 2018.

Samuelson, Paul. 1939. "A Synthesis of the Principle of Acceleration and the Multiplier." Journal of Political Economy, Vol. 47 (6), p. 786-797.

S\&P Capital. 2014. "Buying Outperformance: Do Share Repurchase Announcements Lead to Higher Returns?" Quantamental Research, January 2014. S\&P Capital IQ. 
ANNeX TABLe 1

Annex Table 1: Jorgenson and Siebert Model (1998-2014): Regression Coefficients

\begin{tabular}{rrrrr}
\hline & Estimate & Std. Error & t value & $\operatorname{Pr}(>|\mathrm{t}|)$ \\
\hline (Intercept) & 1.8391 & 0.0178 & 103.30 & 0.000 \\
L(ts(1/ts(EPNH.CAPSTOCK)), 1) & -10.6379 & 0.1753 & -60.67 & 0.000 \\
L(ts(Y_actual_qoq), 1) & 0.0001 & 0.0007 & 0.21 & 0.834 \\
L(ts(Y_actual_qoq), 2) & 0.0002 & 0.0007 & 0.31 & 0.759 \\
L(ts(Y_actual_qoq), 3) & 0.0011 & 0.0007 & 1.45 & 0.150 \\
L(ts(Y_actualqoq), 4) & 0.0020 & 0.0007 & 2.78 & 0.006 \\
L(ts(Y_actual_qoq), 5) & 0.0023 & 0.0007 & 3.11 & 0.002 \\
L(ts(Y_actual_qoq), 6) & 0.0024 & 0.0007 & 3.26 & 0.001 \\
L(ts(Y_actualqoq), 7) & 0.0024 & 0.0007 & 3.30 & 0.001 \\
L(ts(Y_actual_qoq), 8) & 0.0023 & 0.0007 & 3.20 & 0.002 \\
L(ts(Y_actual_qoq), 9) & 0.0026 & 0.0007 & 3.51 & 0.001 \\
L(ts(Y_actual_qoq), 10) & 0.0020 & 0.0007 & 2.67 & 0.009 \\
L(ts(Y_actual_qoq), 11) & 0.0023 & 0.0007 & 3.14 & 0.002 \\
L(ts(Y_actual_qoq), 12) & 0.0029 & 0.0007 & 4.25 & 0.000 \\
\hline
\end{tabular}

Source: Author's estimates. 


\begin{tabular}{|c|c|c|c|c|c|c|}
\hline Name & Variable name & Source & Code & Provider & Frequency & Transformation \\
\hline $\begin{array}{l}\text { Aggregate demand; output; GDP } \\
\end{array}$ & Real Gross Domestic Product (Bil.Chn.2009\$) & $\mathrm{BEA} / 1$ & GDPHA@USECON & Haver & quarterly & $\log$ idx, log diff \\
\hline Bank lending standards & $\begin{array}{l}\text { Net Percentage of Domestic Banks Tightening Standards for Commercial and } \\
\text { Industrial Loans to Large and Middle-Market Firms }\end{array}$ & Fed Board $/ 2$ & DRTSCILM & FRED & quarterly & none \\
\hline Capital stock: Nonresidential private fixed assets (NPFA) & Real Net Stock: Private Fixed Nonresidential Assets (Bil.Chn.2009\$) & BEA & EPNH@CAPSTOCK & Haver & annual & $\log$ idx, log diff \\
\hline Capital stock: NPFA: Equipment & Real Net Stock: Private Fixed Nonresidential Equip (Bil.Chn.2009\$) & BEA & EPNEH@CAPSTOCK & Haver & annual & $\log$ idx, log diff \\
\hline Capital stock: NPFA: Intellectual property products & Real Net Stock: Pvt Fxd Nonres Intellectual Property Products(Bil.Chn.2009\$) & BEA & EPNPH@CAPSTOCK & Haver & annual & $\log$ idx, log diff \\
\hline Capital stock: NPFA: Structures & Real Net Stock: Private Fixed Nonresidential Structures (Bil.Chn.2009\$) & BEA & EPNSH@CAPSTOCK & Haver & annual & $\log$ idx, log diff \\
\hline Consensus one-year ahead GDP growth forecast & Survey of Professional Forecasters (SPF) 4-quarters ahead PGDP forecast, mean & $\mathrm{SPF} / 3$ & dpgdp4 & SPF & quarterly & none \\
\hline Consumer price inflation & $\begin{array}{l}\text { Consumer Price Index for All Urban Consumers: All Items, Percent Change from } \\
\text { Year Ago, Quarterly, Seasonally Adjusted }\end{array}$ & BLS $/ 4$ & CPIAUCSL_PC1 & FRED & quarterly & $\log i d x$ \\
\hline Consumer sentiment & University of Michigan: Consumer sentiment & $\begin{array}{l}\text { University of } \\
\text { Michigan }\end{array}$ & UMCSENT & FRED & monthly & $\log i d x$ \\
\hline Depreciation: NPFA & Depreciation: Private Nonresidential Fixed Assets (Bil.Chn.2009\$) & BEA & KPNH@CAPSTOCK & & annual & $\log$ idx, log diff \\
\hline Depreciation: NPFA: Equipment & Depreciation: Private Nonresidential Fixed Assets: Equip (Bil.Chn.2009\$) & BEA & KPNEH@CAPSTOCK & Haver & annual & $\log$ idx, log diff \\
\hline Depreciation: NPFA: Intellectual property products & Depreciation: Pvt Nonres Fxd Assets: Intellectual Property Prods (Bil.Chn.2009\$) & BEA & KPNPH@CAPSTOCK & Haver & annual & $\log$ idx, log diff \\
\hline Depreciation: NPFA: Structures & Depreciation: Private Nonresidential Fixed Assets: Structures (Bil.Chn.2009\$) & BEA & KPNSH@CAPSTOCK & Haver & annual & $\log$ idx, log diff \\
\hline Economic policy uncertainty & Economic Policy Uncertainty Index for United States & Baker et al (2012) & USEPUINDXD & FRED & daily & none \\
\hline Equity returns & Russell $1000^{\circ}$ Total Market Index, index, $\mathrm{q} / \mathrm{q}$ change & FTSE Russell & RU1000TR & FRED & daily & none \\
\hline Equity valuations & Russell $1000^{\circ}$ Total Market Index, index & FTSE Russell & RU1000TR & FRED & daily & $\log i d x$ \\
\hline Exports & Real Exports of Goods \& Services (SAAR, Bil.Chn.2009\$) & BEA & $\mathrm{XH}$ & Haver & quarterly & $\log$ idx, log diff \\
\hline Federal funds rate (proxy for interest rate level) & Effective Federal Funds Rate & $\begin{array}{l}\text { Federal Reserve } \\
\text { Board }\end{array}$ & DFF & FRED & daily & none \\
\hline Financial conditions index & Chicago Fed National Financial Conditions Index & Federal Reserve & $\mathrm{NFCl}$ & FRED & weekly & none \\
\hline FX rate & Real Trade-Weighted Exch Value of US\$ vs Major Currencies (Mar-73=100) & $\begin{array}{l}\text { Federal Reserve } \\
\text { Board }\end{array}$ & FXTWMC & Haver & daily & $\log i d x$ \\
\hline High yield (corporate) spread & ICE BofAML US High Yield Master II Option-Adjusted Spread & ICE/BofAML & BAMLHOAOHYM2 & FRED & & none \\
\hline Industrial production & Industrial Production Index (SA, 2012=100) & Fed Board & & Haver & quarterly & $\log$ idx, $\log$ diff \\
\hline Inflation expectation & Median expected price change next 12 months, Surveys of Consumers & $\begin{array}{l}\text { University of } \\
\text { Michigan }\end{array}$ & MICH & FRED & monthly & none \\
\hline Inflation gap & Actual consumer price inflation minus target (distance actual to target) & Own $/ 5$ & CPI_gap & NA & & $\log \mathrm{idx}$ \\
\hline Manufacturers' new orders & Manufacturers' New Orders: Nondefense Capital Goods (SA, Mil.1982SS) & CENSUS & NMONC & Haver & quarterly & $\log$ idx, $\log$ diff \\
\hline Manufacturing and trade sales & Real Manufacturing \& Trade Sales: All Industries (SA, Mil.Chn.2009\$) & BEA & TSTH & Haver & quarterly & $\log$ idx, log diff \\
\hline Net capital stock: Equipment, oil and gas extraction & Net Stock: Private Equipment: Oil and Gas Extraction (Hist.Cost, Bil.S) & BEA & EPPB1ET@CAPSTOCK & Haver & annual & $\log$ idx $x$ log diff \\
\hline Net capital stock: Structures, oil and gas extraction & Net Stock: Private Structures: Oil and Gas Extraction (Hist.Cost, Bil.\$) & BEA & EPPB1ST@CAPSTOCK & Haver & annual & $\log$ idx, log diff \\
\hline Nonresidential private fixed investment (NPFI) & Investment: Private Nonresidential Fixed Assets (Bil.Chn.2009\$) & BEA & ZPNH@CAPSTOCK & Haver & annual & $\log$ idx, log diff \\
\hline NPFI: Equipment & Investment: Private Nonresidential Fixed Assets: Equip (Bil.Chn.2009\$) & BEA & ZPNEH@CAPSTOCK & Haver & annual & $\log$ idx, log diff \\
\hline $\begin{array}{l}\text { NPFI: Intellectual property products } \\
\text { s. }\end{array}$ & Investment: Pvt Nonres Fxd Assets: Intellectual Property Prods(Bil.Chn.2009\$) & BEA & ZPNPH@CAPSTOCK & Haver & annual & $\log$ idx, log diff \\
\hline NPFI: Intellectual property: Oil and ga & Investment: Intellectual Property: Oil and Gas Extraction (Hist.Cost, Bil.\$) & BEA & ZPPB1PT@CAPSTOCK & Haver & annual & $\log$ idx, log diff \\
\hline NPFI: Oil and gas extraction & Investment: Pvt Fxd Assets: Oil and Gas Extraction (Hist.Cost, Bil.\$\$) & BEA & ZPPB1T@CAPSTOCK & Haver & annual & $\log$ idx, log diff \\
\hline NPFI: Structures & Investment: Private Nonresidential Fixed Assets: Structures (Bil.Chn.2009\$) & BEA & ZPNSH@CAPSTOCK & Haver & annual & $\log$ idx, log diff \\
\hline Oil price & Global price of WTI Crude & IMF & POILWTIUSDQ & FRED & quarterly & $\log \mathrm{idx}$ \\
\hline $\begin{array}{l}\text { Personal consumption expenditures (PCE) } \\
\end{array}$ & Real Personal Consumption Expenditures (SAAR, Bil.Chn.2009\$) & BEA & $\mathrm{CH}$ & Haver & & $\log$ diff \\
\hline Political conflict; partisan conflict & Partisan Conflict Index & Azzimonti (2018) & NA & Federal Reserve & monthly & none \\
\hline Productivity & Average Weekly Hours: Prod \& Nonsupervisory: Manufacturing (SA, Hrs) & BLS & LRMANUA & Haver & quarterly & $\log i d x$ \\
\hline Profits & Real Corporate Profits After Tax (SAAR, Bil.Chn.2009\$) & BEA & YCATH@USECON & Haver & quarterly & $\log$ idx, log diff \\
\hline Rate hikes (changes in federal funds rate) & Effective Federal Funds Rate, $q / q$ change & Fed Board & DFF_qoq & FRED & daily & none \\
\hline $\begin{array}{l}\text { Residential private fixed investment (RPFI) } \\
\end{array}$ & Investment: Res Fixed Assets: Private (Bil.Chn.2009\$) & & ZPRT@CAPSTOCK & Haver & quarterly & $\log$ idx, log diff \\
\hline Relative price of investment & Relative price of investment goods (investment to consumption deflator) & Federal Reserve & PIRIC & FRED & quarterly & none \\
\hline SPF dispersion & Range of individual SPF one-year ahead growth forecasts ( $\mathrm{max}$ minus $\mathrm{min}$ ) & Own & NA & SPF & quarterly & $\log i d x$ \\
\hline Term spread, 10-year minus 2-year Treasury yield & 10-Year Treasury Constant Maturity Minus 2-Year Treasury Constant Maturity & Federal Reserve & T10Y2Y & FRED & daily & none \\
\hline Tightening of lending standards & $\begin{array}{l}\text { Net Percentage of Domestic Banks Reporting Stronger Demand for Commercial } \\
\text { and Industrial Loans from Large and Middle-Market Firms }\end{array}$ & $\begin{array}{l}\text { Federal Reserve } \\
\text { Board }\end{array}$ & DRSDCILM & FRED & quarterly & none \\
\hline $\mathrm{VIX}$ & CBOE Volatility Index: VIX & CBOE & VIXCLS & FRED & daily & $\log i \mathrm{dx}$ \\
\hline
\end{tabular}

; of the Federal Reserve; /3 Survey of Professional Forecasters; / 4 Bureau of Labor Statistics; /5 variables defined by author. 